\title{
Evaluating the degree of oxygenation of organic aerosol during foggy and hazy days in Hong Kong using high-resolution time-of-flight aerosol mass spectrometry (HR-ToF-AMS)
}

\author{
Y. J. Li ${ }^{1}$, B. Y. L. Lee ${ }^{1}$, J. Z. Yu ${ }^{1,2}$, N. L. Ng ${ }^{3}$, and C. K. Chan ${ }^{1,4}$ \\ ${ }^{1}$ Division of Environment, Hong Kong University of Science and Technology, Hong Kong, China \\ ${ }^{2}$ Department of Chemistry, Hong Kong University of Science and Technology, Hong Kong, China \\ ${ }^{3}$ School of Earth and Atmospheric Sciences, Georgia Institute of Technology, Atlanta, Georgia, USA \\ ${ }^{4}$ Department of Chemical and Biomolecular Engineering, Hong Kong University of Science and Technology, Hong Kong, \\ China
}

Correspondence to: C. K. Chan (keckchan@ust.hk)

Received: 28 January 2013 - Published in Atmos. Chem. Phys. Discuss.: 8 February 2013

Revised: 16 July 2013 - Accepted: 17 July 2013 - Published: 3 September 2013

\begin{abstract}
The chemical characteristics of organic aerosol (OA) are still poorly constrained. Here we present observation results of the degree of oxygenation of OA based on high-resolution time-of-flight aerosol mass spectrometry (HR-ToF-AMS) measurements made at a coastal site in Hong Kong from late April to the end of May in 2011. Two foggy periods and one hazy period were chosen for detailed analysis to compare the changes in the degree of oxygenation of OA due to different processes. Using HR-ToF-AMS measured inorganic species as input, the Extended Aerosol Inorganic Model (E-AIM) predicted a fine-particle liquid water content $\left(\mathrm{LWC}_{\mathrm{fp}}\right)$ up to $85 \mu \mathrm{g} \mathrm{m}^{-3}$ during the foggy days. Particle concentration as measured by HR-ToF-AMS was up to $60 \mu \mathrm{g} \mathrm{m}^{-3}$ during the hazy days and up to $30 \mu \mathrm{g} \mathrm{m}^{-3}$ during the foggy days. The degree of oxygenation of OA, as indicated by several parameters including the fraction of $m / z 44$ in organic mass spectra $\left(f_{44}\right)$, the elemental ratio of oxygen to carbon $(\mathrm{O}: \mathrm{C})$, and the carbon oxidation state $\left(\overline{\mathrm{OS}}_{\mathrm{c}}\right)$, was evaluated against the odd oxygen $\left(\mathrm{O}_{\mathrm{x}}\right)$ concentration, $\mathrm{LWC}_{\mathrm{fp}}$, ionic strength (IS), and in situ $\mathrm{pH}\left(\mathrm{pH}_{\mathrm{is}}\right)$. Observations suggest that the high concentration of $\mathrm{OA}$ (on average $\left.11 \mu \mathrm{g} \mathrm{m}^{-3}\right)$ and the high degree of oxygenation $\left(f_{44}=0.15\right.$, $\mathrm{O}: \mathrm{C}=0.51$, and $\overline{\mathrm{OS}}_{\mathrm{c}}=-0.31$ ) during the hazy period were mainly due to gas-phase oxidation. During the foggy periods with low photochemical activities, the degree of oxygenation of OA was almost as high as that on the hazy days, and significantly higher than that during non-foggy/non-hazy days. However, the OA evolved quite differently in the two
\end{abstract}

foggy periods. The first foggy period in late April saw a larger $\mathrm{LWC}_{\mathrm{fp}}$ and a lower $\mathrm{O}_{\mathrm{x}}$ concentration and the $\mathrm{OA}$ were made up of $\sim 20 \%$ semi-volatile oxygenated organic aerosol (SVOOA) as resolved by positive matrix factorization (PMF). In the second foggy period in mid-May, higher $\mathrm{O}_{\mathrm{x}}$ concentration and lower $\mathrm{LWC}_{\mathrm{fp}}$ were observed, and the OA were found to contain $>50 \%$ low-volatility oxygenated organic aerosols (LVOOA). An examination of the particle characteristics $\left(\mathrm{pH}_{\mathrm{is}}\right.$, IS, and $\mathrm{LWC}_{\mathrm{fp}}$ ) suggests that partitioning may have been the dominating process through which oxygenated species were incorporated into the particle phase during the first foggy period, while oxidation in the aqueous phase dominated over gas-phase processes during the second foggy period.

\section{Introduction}

Organic aerosols (OA) are the least understood components of atmospheric particulate matter (PM) (Kanakidou et al., 2005). One of the most challenging tasks in atmospheric science is the characterization of secondary organic aerosol (SOA) to understand their formation (Hallquist et al., 2009). Apart from the fact that SOA contains numerous organic compounds with molecular identities yet unknown to us, their dynamic nature further complicates the characterization as they evolve through various chemical (e.g., reactions) and physical (e.g., partitioning)

Published by Copernicus Publications on behalf of the European Geosciences Union. 
processes. Using high-time-resolution aerosol mass spectrometric (AMS) data, Jimenez et al. (2009) found that the evolution processes can occur in a matter of hours. Hightime-resolution AMS thus allows us to examine short-term episodes that traditional time-integrated sampling techniques may not be able to capture.

In Hong Kong a meteorological transition from continental outflow (wintertime) to marine inflow (summertime) occurs during late spring (March) and early summer (May), bringing with it huge disruptions to the local meteorological conditions that strongly affect air quality (Wang et al., 2003; Yu et al., 2004). During this period, low clouds and fog are common due to the moisture-laden air masses from the sea (Ho, 2003). Meanwhile long-range transport brings dry air with pollutants from the inland area (Fang et al., 1999), and high photochemical activity in this subtropical area induces secondary aerosol formation resulting in the formation of haze. Therefore, fog and haze, as two synoptic conditions examined in this study, are responsible for severe visibility reduction during late spring and early summer in Hong Kong. Despite studies on day-to-day variations in air pollutants (Wang et al., 2003; Louie et al., 2005), examination of OA, especially SOA, during episodic periods with high time resolution is still rare. In summer in Hong Kong, the dominating process in SOA formation is reported (Hu et al., 2008) to be the traditional gas-phase oxidation followed by absorptive partitioning (Pankow, 1994). However, other processes that have been proposed to be important - e.g., aqueous-phase processing (Blando and Turpin, 2000; Ervens et al., 2011) in cloud, fog, and wet particles - are rarely explored in this region. Yao et al. (2004) and Yu et al. (2005) investigated the correlation between oxalic acid, as a typical secondary organic species, and sulfate, as a typical secondary inorganic species. They proposed that oxalic acid is mainly formed through cloud processing. Hence, cloud processing could in fact contribute substantially to SOA formation in Hong Kong (Huang et al., 2011).

Early field studies attributed the enhanced amounts of small carboxylic acids observed in airborne aqueous droplets such as fog to efficient scavenging (Herckes et al., 2002). Recent studies (Ervens et al., 2011, and references therein) have shown that formation of oxygenated organic compounds in atmospheric aqueous droplets is efficient. Besides laboratory studies demonstrating the SOA formation potential of aqueous-phase oxidation (Tan et al., 2009; Lee et al., 2011), there are a number of field studies to evaluate the importance of either enhanced partitioning (or scavenging) or aqueousphase oxidation in atmospheric aqueous droplets in SOA formation (Hersey et al., 2011; Zhang et al., 2012). Hennigan et al. $(2008,2009)$ suggested that elevated SOA production was due to enhanced uptake of semi-volatile water soluble organic carbon (WSOC) onto the particle phase, followed by further oxidation. Dall'Osto et al. (2009) observed the production of both inorganic and organic secondary species during a fog event in London using online mass spectromet- ric techniques. By comparing SOA formation during foggy days and non-foggy days in the Indo-Gangetic Plain, Kaul et al. (2011) attributed the enhanced SOA production during foggy days to aqueous-phase chemistry. Sorooshian et al. (2010) showed that oxygenated organics, such as individual organic acids and acidic groups as indicated by $m / z 44$ in AMS measurements, contributed to a higher organic mass fraction in particles in the vicinity of clouds. The abundance of oxygenated organics increased as relative humidity (RH) and aerosol hygroscopicity increased, due to favorable partitioning and efficient chemistry in the aqueous phase in both cloud droplets and wet aerosol particles. Ge et al. (2012) showed that aqueous-phase processes altered aerosol chemistry and microphysics by forming both secondary inorganic and organic aerosols during foggy periods. In these previous studies, the role of aqueous-phase chemistry in SOA formation was evaluated using a wide range of indicators, from a single compound (e.g., oxalic acid) to a practically defined surrogate ion (e.g., $m / z$ 44) or group (e.g., WSOC). Although these studies demonstrated enhanced oxygenated organic aerosol formation due to aqueous-phase chemistry, the contribution from gas-phase processes and that from aqueous-phase processes (including cloud, fog, and wet particles) are seldom compared directly with periods dominated by the aqueous-phase processes and periods dominated by the gas-phase processes.

Recent advances in aerosol mass spectrometry (DeCarlo et al., 2006) and factor analysis (Lanz et al., 2007; Ulbrich et al., 2009; Zhang et al., 2011) of mass spectrometric data have allowed us to obtain comprehensive and moderately specific chemical information on the bulk characteristics of OA. One such characteristic is the degree of oxygenation of OA, which plays a central role in aerosol chemistry and subsequent effects of OA during the evolution due to atmospheric oxidation (Jimenez et al., 2009). Using positive matrix factorization (PMF), it was found that oxygenated organic aerosols (OOA), a surrogate of SOA, make up on average over $60 \%$ (Lanz et al., 2007) of the organic $\mathrm{PM}_{1}$ (PM with diameter less than $1 \mu \mathrm{m}$ ) and more than $80 \%$ in remote areas (Morgan et al., 2010). The degree of oxygenation was suggested to affect aerosol hygroscopicity (Chang et al., 2010; Massoli et al., 2010; Duplissy et al., 2011; Lambe et al., 2011; Wong et al., 2011; Martin et al., 2013), although some other studies (Frosch et al., 2011; Lathem et al., 2013) found opposing results. It is therefore desirable to investigate the degree of oxygenation of $\mathrm{OA}$ in different locations to determine their formation and transformation processes and subsequent effects on aerosol properties.

Here we present observation results from a field campaign conducted from April to May (a generally humid period with an average $\mathrm{RH}$ of $\sim 80 \%$ ) at a coastal site in Hong Kong. Data from two foggy periods and one haze episode are discussed here in detail. The aim of the current work was to evaluate the degree of oxygenation of OA of aqueous droplets and drier particles during foggy and hazy 
days, respectively. PM compositions were measured with an Aerodyne high-resolution time-of-flight aerosol mass spectrometer (HR-ToF-AMS). Using particle compositions from AMS data and the aerosol thermodynamic model Extended Aerosol Inorganic Model (E-AIM) (Clegg et al., 1998), the ionic strength (IS), liquid water content in fine particles $\left(\mathrm{LWC}_{\mathrm{fp}}\right)$, and in situ $\mathrm{pH}$ were estimated, and their effects on the SOA characteristics, as revealed by AMS data and PMF, were examined.

\section{Experimental}

\subsection{Sampling site}

The sampling site is located on the campus of the Hong Kong University of Science and Technology (HKUST), which sits on the hill side of Clear Water Bay on the east coast of Hong Kong. The area is suburban and experiences frequent high RH and foggy days in springtime. Both particle and gas measurements were taken at the HKUST Air Quality Supersite $\left(22^{\circ} 20^{\prime} \mathrm{N}, 114^{\circ} 16^{\prime} \mathrm{E}\right)$ using a number of online instruments (http://envr.ust.hk/supersite/). The supersite sits on the rooftop of a pump house on the seafront with a short distance (approximately $30 \mathrm{~m}$ ) to the sea. The sampling inlets were approximately $20 \mathrm{~m}$ above sea level. During the measurement period (25 April-1 June 2011), the hourly average RH and temperature were $80.3 \pm 12.3 \%$ (35.6-93.9\%) and $24.6 \pm 2.4^{\circ} \mathrm{C}\left(18.5-31.7^{\circ} \mathrm{C}\right)$.

\subsection{Measurements}

Non-refractory $\mathrm{PM}_{1}\left(\mathrm{NR}-\mathrm{PM}_{1}\right)$ constituents including sulfate, nitrate, ammonium, chloride, and organics were measured with an Aerodyne HR-ToF-AMS operated under V, pToF, and $\mathrm{W}$ modes. The principle behind the instrument has been described in detail elsewhere (DeCarlo et al., 2006), and will only be briefly described here. In pToF mode, the instrument performs particle sizing based on particle time of flight with the aid of a chopper and gives size-resolved chemical composition data in vacuum aerodynamic diameter $\left(D_{\text {va }}\right)$ (DeCarlo et al., 2004). In V mode, the shorter traveling path for ions in the ion time-of-flight (iToF) chamber gives a mass spectral resolving power of approximately 2000 (DeCarlo et al., 2006) and better sensitivity. In W mode, the mass spectral resolving power is approximately 4000 (DeCarlo et al., 2006), but the signal-to-noise ratio is lower. The instrument was operated alternately between the V + pToF combined mode and the $\mathrm{W}$ mode for $5 \mathrm{~min}$ each. The sampling inlet was shared by a few instruments, and an extra pump was used to maintain the required flow rate $\left(16.7 \mathrm{~L} \mathrm{~min}^{-1}\right)$ for the $\mathrm{PM}_{2.5}$ size cut. A diffusion dryer (BMI, San Francisco, CA) was placed before the inlet of HR-Tof-AMS to remove particulate water. Although we used the $\mathrm{LWC}_{\mathrm{fp}}$ estimated from E-AIM as one of our parameters (see below), we measured dried chemical composition by AMS for the following reasons: (1) the presence of liquid water in the sampled particles may complicate the collection efficiency (CE) applied; (2) the RH at the AMS inlet would be different from that in the ambient environment even if no dryer was used, which makes the measured liquid water content less representative; and (3) due to the overlapping of $\mathrm{m} / \mathrm{z}$ values and the fact that more than one species (e.g., organics and sulfate) can contribute to water signals, the quantification of particle-phase water in AMS would need extensive modification to the fragmentation table during data analysis. In this study, only slight changes were made to adjust contributions of gas-phase ions ${ }^{15} \mathrm{~N}^{14} \mathrm{~N}^{+}$to $m / z 29$ and $\mathrm{CO}_{2}^{+}$ to $m / z$ 44. Ionization efficiency (IE) calibrations were performed weekly using size-selected ammonium nitrate particles $\left(350 \mathrm{~nm}\right.$ in mobility diameter, $\left.D_{\mathrm{m}}\right)$. The flow rate of the inlet $\left(\sim 80 \mathrm{~mL} \mathrm{~min}^{-1}\right)$ and sizing (using standard PSL particles, Duke Scientific, Palo Alto, CA) were calibrated before and after the campaign with negligible differences observed. Gaseous species $\left(\mathrm{NO}_{2}\right.$ and $\left.\mathrm{O}_{3}\right)$ were measured with standard gas analyzers (Teledyne API). Meteorological parameters (RH, temperature, solar irradiance, visibility, etc.) were measured by an automatic weather station mounted on a tower right next to the pump house on which the supersite sits. Daily average cloud coverage data were obtained from the Hong Kong Observatory.

\subsection{Data analysis}

The AMS unit-mass-resolution (UMR) data were analyzed using the data analysis toolkit SQUIRREL and the AMS high-resolution (HR) data using PIKA (Sueper, 2012). The data-processing procedures have been detailed in previous studies (Allan et al., 2004; Aiken et al., 2007, 2008). A CE of 0.5, which has been widely used in field studies employing AMS with a dryer installed in front of the equipment's particle inlet (Allan et al., 2003; Aiken et al., 2009), was applied during the whole campaign. Middlebrook et al. (2012) recently suggested that the CE should be composition-dependent, with influences of (1) high nitrate content, (2) biomass burning aerosols, and (3) high acidity, suggesting that the CE depends on the state (liquid or solid) of the particles. Neither of the first two influences was the case for our campaign; that is, we found low nitrate $(\sim 4 \%$ by mass in $\mathrm{PM}_{1}$ ) and negligible signals indicating biomass burning at $m / z 60,73,137$, and 167 (Alfarra et al., 2007; Li et al., 2011b). As for acidity, we observed a measured-topredicted $\mathrm{NH}_{4}^{+}$ratio $\left(\frac{\mathrm{NH}_{4, \mathrm{~m}}^{+}}{\mathrm{NH}_{4}, \mathrm{p}^{+}}\right.$, see Eq. 1) of 0.7-0.9, with an average of 0.82 . This average value is higher than the limit (0.75) above which bouncing decreases and CE starts to increase from 0.45 (Middlebrook et al., 2012). The measuredto-predicted $\mathrm{NH}_{4}^{+}$ratio is defined as

$$
\frac{\mathrm{NH}_{4, \mathrm{~m}}^{+}}{\mathrm{NH}_{4, \mathrm{p}}^{+}}=\frac{\mathrm{NH}_{4, \mathrm{~m}}^{+}}{18 \times\left(2 \times \frac{\mathrm{SO}_{4, \mathrm{~m}}^{2-}}{96}+\frac{\mathrm{NO}_{3, \mathrm{~m}}^{-}}{62}+\frac{\mathrm{Cl}_{\mathrm{m}}^{-}}{35.5}\right)},
$$



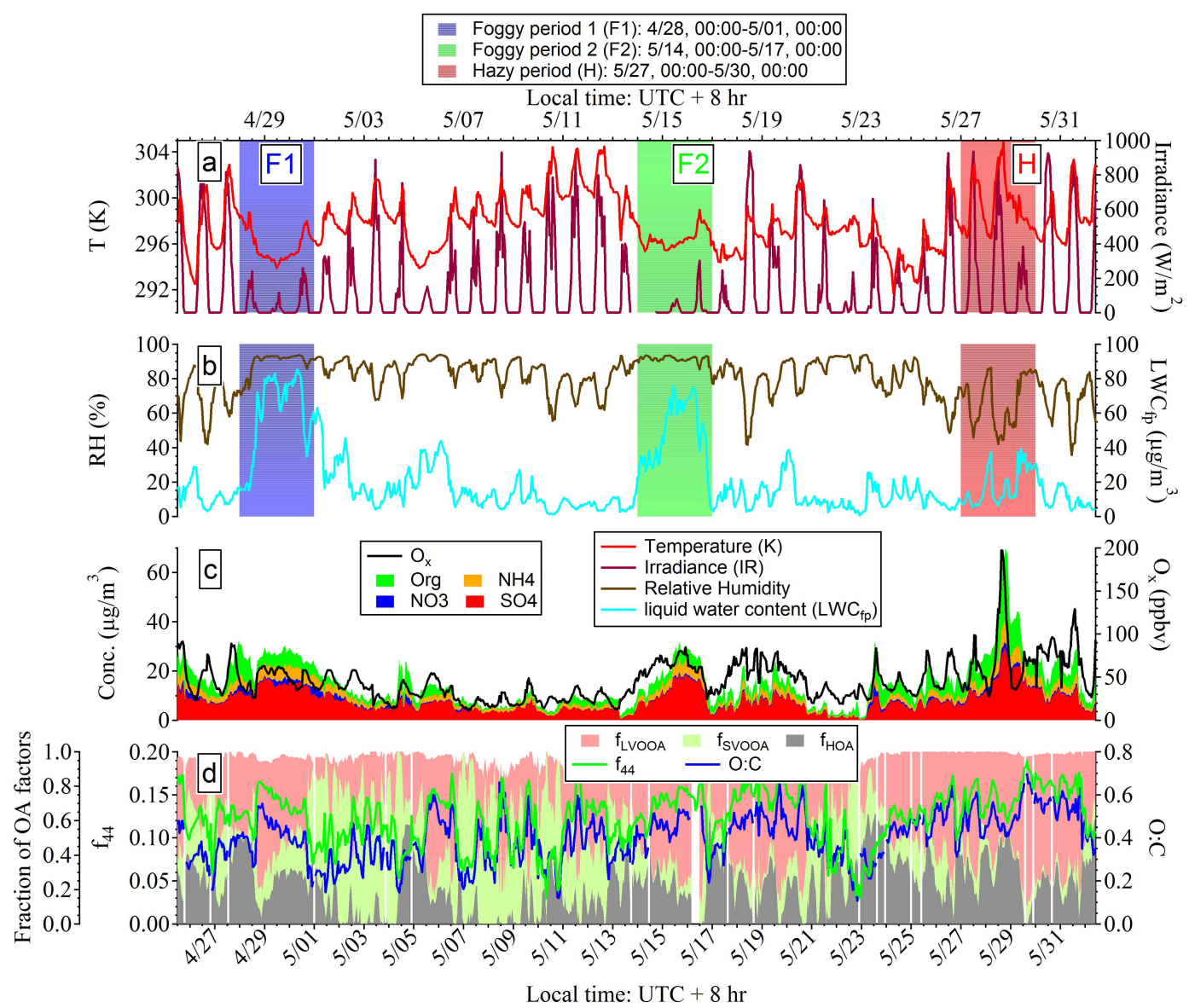

Fig. 1. (a, b) Meteorological conditions (temperature, irradiance, $\mathrm{RH})$ and estimated fine-particle liquid water content $\left(\mathrm{LWC}_{\mathrm{fp}}\right),(\mathbf{c}) \mathrm{NR}_{\mathrm{P}} \mathrm{PM} \mathrm{H}_{1}$ species (sulfate, nitrate, ammonium, and organics) and odd oxygen $\left(\mathrm{O}_{\mathrm{x}}=\mathrm{O}_{3}+\mathrm{NO}_{2}\right)$ concentrations, and (d) fractions of PMF-resolved OA factors (HOA, SVOOA, and LVOOA) and $f_{44}$ and $\mathrm{O}: \mathrm{C}$ ratios of organics. Three periods - foggy period \#1 (F1), foggy period \#2 (F2), and hazy period $(\mathrm{H})$ - were chosen for further discussion.

where $\mathrm{NH}_{4, \mathrm{~m}}^{+}, \mathrm{SO}_{4, \mathrm{~m}}^{2-}, \mathrm{NO}_{3, \mathrm{~m}}^{-}$, and $\mathrm{Cl}_{\mathrm{m}}^{-}$are the measured mass concentrations of ammonium, sulfate, nitrate, and chloride, respectively, while $\mathrm{NH}_{4, \mathrm{p}}^{+}$is the predicted mass concentration of ammonium with the assumption that ammonium is the only cation to balance the anions. For particles overwhelmingly dominated by sulfate as in this study, a CE of 0.5 might lead to an underestimate of 10-20\% of PM species concentrations. However, the parameters used to represent the degree of oxygenation of OA will not be affected by the choice of CE.

This work focuses on data from two foggy periods with high RH (F1 and F2 in Fig. 1), and one hazy period with low RH but high PM concentration (H in Fig. 1). Using the inorganic composition measured by HR-ToF-AMS, the $\mathrm{LWC}_{\mathrm{fp}}$ was estimated by applying E-AIM II (Clegg et al., 1998) with the formation of solids prohibited. Since RH values during this campaign were generally high (average $80 \%$ ), the assumption of no solid formation is appropriate most of the time, except for the $\mathrm{H}$ period. Organics were not included in our estimation of $\mathrm{LWC}_{\mathrm{fp}}$, but they were most likely to pro- hibit solid formation (Chan et al., 2008) since most of the organics measured were highly oxygenated compounds (see below). Furthermore, the contributions of OA in hygroscopicity are small because of the dominance of the inorganic components, in particular sulfate. IS in $\mathrm{mol} \mathrm{kg}^{-1}$ (molality) based on the inorganic species and $\mathrm{LWC}_{\mathrm{fp}}$ was estimated as follows:

$$
\begin{aligned}
& \mathrm{IS}=\frac{1}{2} \sum C_{i} z_{i}^{2} \\
& \bar{F} \frac{1}{2} \times \frac{\left(M_{\mathrm{SO}_{4}} / 96\right) \times 2^{2}+\left(M_{\mathrm{NO}_{3}} / 62\right) \times 1^{2}+\left(M_{\mathrm{NH}_{4}} / 18\right) \times 1^{2}+\left(M_{\mathrm{Chl}} / 35.5\right) \times 1^{2}}{0.001 \times \mathrm{LWC}_{\mathrm{fp}}}
\end{aligned}
$$

where $M_{\mathrm{SO}_{4}}, M_{\mathrm{NO}_{3}}, M_{\mathrm{NH}_{4}}$, and $M_{\mathrm{Chl}}$ are mass concentrations $\left(\mu \mathrm{g} \mathrm{m}^{-3}\right)$ of sulfate, nitrate, ammonium, and chloride, respectively, measured by HR-ToF-AMS; and $\mathrm{LWC}_{\mathrm{fp}}$ is the mass concentration $\left(\mu \mathrm{g} \mathrm{m}^{-3}\right)$ of liquid water content in fine particles estimated from E-AIM II. In situ $\mathrm{pH}\left(\mathrm{pH}_{\mathrm{is}}\right)$ of fine particles was calculated from the proton $\left(\mathrm{H}^{+}\right)$molar fraction $\left(f_{\mathrm{H}^{+}}\right)$, the activity coefficient based on molar fraction $\left(\gamma_{\mathrm{H}^{+}}\right)$, total moles of all condensed-phase species $\left(n_{\mathrm{tot}}\right)$, and 
the volume $\left(V_{\mathrm{aq}}, \mathrm{m}^{3}\right)$ of the aqueous phase, as below:

$\mathrm{pH}_{\mathrm{is}}=-\log \left(\frac{n_{\mathrm{tot}} \times f_{\mathrm{H}^{+}} \times \gamma_{\mathrm{H}^{+}}}{0.001 \times V_{\mathrm{aq}}}\right)$.

All these parameters were generated from E-AIM II with the hourly averaged inorganic compositions measured by HRToF-AMS. Note that the estimation of $\mathrm{LWC}_{\mathrm{fp}}$ is highly sensitive to RH measurement uncertainty, which in our case is $3 \%$ in $\mathrm{RH}$ for $\mathrm{RH}>95 \%$ and $2 \%$ in $\mathrm{RH}$ for $\mathrm{RH}<95 \%$. Using the highest uncertainty of $3 \%$ for $\mathrm{RH}$ measurement, the uncertainty of $\mathrm{LWC}_{\mathrm{fp}}$ estimation is $-20 \%$ to $+40 \%$ for $\mathrm{LWC}_{\mathrm{fp}}<50 \mu \mathrm{g} \mathrm{m}^{-3}$ and $-30 \%$ to $+100 \%$ (a factor of 2 ) for $\mathrm{LWC}_{\mathrm{fp}}$ at $\sim 80 \mu \mathrm{g} \mathrm{m}^{-3}$ (the highest estimated in this study). On the other hand, neglecting the water uptake by organics (especially oxygenated ones) might be another source of uncertainty of $\mathrm{LWC}_{\mathrm{fp}}$ estimation. Yet, for particles overwhelmingly dominated by ammonium sulfate ( $>60 \%$ by mass), the contribution of organics to water uptake would be relatively small. Correspondingly, the IS estimation has a highest uncertainty of $-50 \%$ to $+40 \%$, while the $\mathrm{pH}_{\text {is }}$ has a highest uncertainty of $\sim 0.3$ unit. Given the high uncertainties in the estimations of particle characteristics $\left(\mathrm{pH}_{\mathrm{is}}, \mathrm{IS}\right.$, and $\mathrm{LWC}_{\mathrm{fp}}$ ), all discussions below related to $\mathrm{LWC}_{\mathrm{fp}}$, IS, and $\mathrm{pH}_{\mathrm{is}}$ are qualitative without attempting to show any quantitative relationships. Mass spectra of organic aerosols measured by HR-ToF-AMS were also analyzed by PMF with an analysis toolkit (Lanz et al., 2007; Ulbrich et al., 2009; Zhang et al., 2011). Three factors, namely hydrocarbon-like organic aerosol (HOA), semi-volatile oxygenated organic aerosols (SVOOA), and low-volatility oxygenated organic aerosols (LVOOA), were resolved by PMF (Lee et al., 2013, and Section 2 in supporting information). The two OOA factors have been considered as surrogates for SOA (Jimenez et al., 2009) and will be used in the following discussion, along with other indicators including $f_{44}$ (fraction of $m / z 44$ in organic mass spectra) ( $\mathrm{Ng}$ et al., 2010), the elemental ratio of oxygen to carbon (O:C) (Aiken et al., 2008), and the carbon oxidation state $\left(\overline{\mathrm{OS}}_{\mathrm{c}}\right)$ (Kroll et al., 2011$)$ in order to evaluate the degree of oxygenation of OA. Note that if primary sources such as vehicle exhaust and biomass burning contribute to oxygenated organics, the usage OOA factors to represent SOA could lead to an overestimate of SOA. However, it has been shown that vehicle exhaust did not contribute much to oxygenated organics such as oxalic acid in Hong Kong (Huang and $\mathrm{Yu}, 2007)$, and we did not observe elevated tracer ions such as $m / z 60$ and 73 from biomass burning (Alfarra et al., 2007).

\section{Results and discussion}

\subsection{Overview}

Figure 1 shows the overall meteorological conditions, species concentrations, as well as other parameters representing the degree of oxygenation of OA $\left(f_{44}, \mathrm{O}: \mathrm{C}\right.$, and fractions of OA factors from $\mathrm{PMF}$ analysis). Three periods - foggy period \#1 (F1), foggy period \#2 (F2), and hazy period $(\mathrm{H})$ - each lasting for three days, were chosen for further analysis. The two foggy periods F1 and F2 had high $\mathrm{RH}$ (daily average $>85 \%$ ), high $\mathrm{LWC}_{\mathrm{fp}}$, and relatively high $\mathrm{PM}_{1}$ concentrations. The hazy period $(\mathrm{H})$ was the PM episode during the campaign with high $\mathrm{PM}_{1}$ loadings (up to $60 \mu \mathrm{g} \mathrm{m}^{-3}$, Fig. 1c), but the $\mathrm{RH}$ and $\mathrm{LWC}_{\mathrm{fp}}$ during this period were relatively low (Fig. 1b). The foggy weather during F1 and F2 and the hazy condition during $\mathrm{H}$ led to low visibility as shown in the pictures, which were taken with an automatic camera on an island approximately $20 \mathrm{~km}$ south of the sampling site, and the visibility data in Fig. S1.

Table 1 shows all the averages $( \pm \sigma)$ of measured and calculated parameters in those three periods, along with the overall averages of the whole campaign and those of the nonfoggy/non-hazy or "other" periods. The species concentrations and their mass fractions are also shown in the bar plots in Figs. S2 and 2. During the whole campaign, the average $\mathrm{RH}$, temperature, and cloud coverage were $80.3 \%, 24.6^{\circ} \mathrm{C}$, and $71.9 \%$, respectively. The average $\mathrm{PM}_{1}$ species concentrations during the whole campaign (overall) as measured by HR-ToF-AMS were $7.9 \mu \mathrm{g} \mathrm{m}^{-3}$ for sulfate, $0.63 \mu \mathrm{g} \mathrm{m}^{-3}$ for nitrate, $2.5 \mu \mathrm{g} \mathrm{m}^{-3}$ for ammonium, and $4.4 \mu \mathrm{g} \mathrm{m}^{-3}$ for organics. Nitrate concentration determined here could be somewhat $(20-40 \%)$ biased by the presence of interfering organic ions at $\mathrm{m} / \mathrm{z} 30$ and 46, as well as the possible presence of organonitrates (Farmer et al., 2010). Non-refractory chloride (for example, chloride in the form of ammonium chloride) in $\mathrm{PM}_{1}$ made up less than $1 \%$ of the measured mass, and so will not be discussed further here. Meteorological data showed that among the three chosen periods, F1 and F2 were of high $\mathrm{RH}$, low temperature, and high cloud coverage, while $\mathrm{H}$ was of the opposite. The average species concentrations of sulfate, nitrate, ammonium, and organics were higher during the three chosen periods than during the "other" periods, with only one exception - nitrate in F2. Among the organic composition, most of the PMF-resolved OA concentrations (HOA, SVOOA, and LVOOA) were higher during the chosen periods, with a very significant increase in LVOOA, than during the "other" periods. Among the three chosen periods, the $\mathrm{PM}_{1}$ concentration was highest in $\mathrm{H}$ and lowest in $\mathrm{F} 2$. The estimated $\mathrm{LWC}_{\mathrm{fp}}$ was much higher in F1 and F2 than in $\mathrm{H}$. As a result, the average ionic strength in $\mathrm{H}$ was a factor of 4 to 5 higher than in F1 and F2, although the possibility of solid formation in $\mathrm{H}$ cannot be completely ruled out. In terms of acidity, $\mathrm{H}$ was the most acidic period (assuming particles were in aqueous phase), followed by F2, and then F1, 


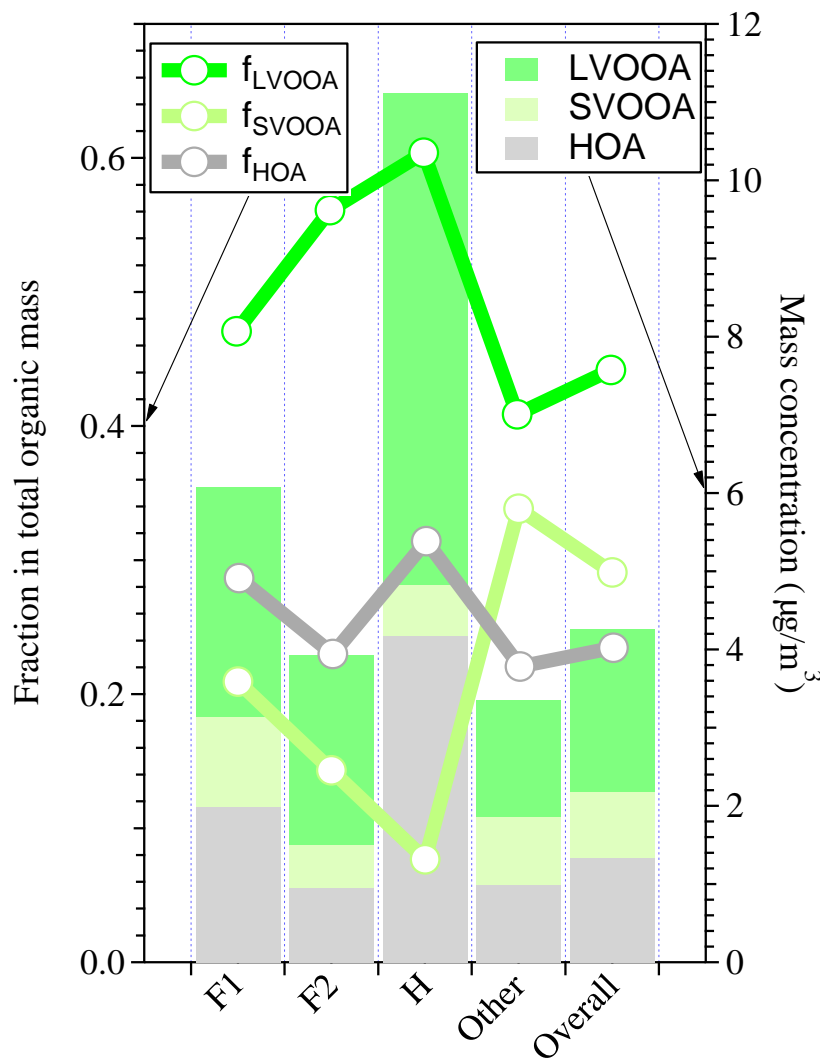

Fig. 2. Mass fraction and concentration of hydrocarbonlike organic aerosols (HOA), semi-volatile oxygenated organic aerosols (SVOOA), and low-volatility oxygenated organic aerosols (LVOOA) during five periods: foggy periods (F1 and F2), hazy period $(\mathrm{H})$, non-foggy and non-hazy period ("other"), and overall period.

because of the high $\mathrm{LWC}_{\mathrm{fp}}$ in the latter two periods. It was the other way around for the average concentration of $\mathrm{O}_{\mathrm{x}}$.

\subsection{Degree of oxygenation of OA}

There are several ways to evaluate the degree of oxygenation of OA based on AMS data. $\mathrm{Ng}$ et al. (2010) used the triangle plot ( $f_{44}$ vs. $f_{43}$, as fractions of the two different $\mathrm{m} / \mathrm{z}$ values in organic spectra) to visualize the relative contributions of $\mathrm{CO}_{2}^{+}(\mathrm{m} / \mathrm{z} 44)$ and $\mathrm{C}_{2} \mathrm{H}_{3} \mathrm{O}^{+} / \mathrm{C}_{3} \mathrm{H}_{7}^{+}(\mathrm{m} / \mathrm{z} 43)$ ions to the organic spectra from UMR-AMS data. Heald et al. (2010) placed the HR-AMS-derived $\mathrm{H}: \mathrm{C}$ and $\mathrm{O}: \mathrm{C}$ ratios in the Van Krevelen diagram ( $\mathrm{H}: \mathrm{C}$ vs. $\mathrm{O}: \mathrm{C}$ ) to infer compositional changes due to different chemical processes. Kroll et al. (2011) utilized the $\mathrm{H}: \mathrm{C}$ and $\mathrm{O}: \mathrm{C}$ ratios to estimate the average carbon oxidation state $\left(\overline{\mathrm{OS}}_{\mathrm{c}} \approx 2 \times \mathrm{O}: \mathrm{C}-\mathrm{H}: \mathrm{C}\right)$ and used it as a metric to evaluate the degree of oxygenation of organics. Recently, Ng et al. (2011) suggested that with some parameterizations that convert $f_{44}$ to $\mathrm{O}: \mathrm{C}$ (Aiken et al., 2008) and $f_{43}$ to $\mathrm{H}: \mathrm{C}$ (Ng et al., 2011), the above three ways of representing the degree of oxygenation of OA can be superimposed into one graph. With only OOAs (SVOOA and LVOOA) from different locations included, $\mathrm{Ng}$ et al. (2011) showed that ambient OOAs clustered within a well-defined band of the transformed triangle plot with a slope of $\sim-0.5$ in the Van Krevelen diagram and $\overline{\mathrm{OS}}_{\mathrm{c}}$ of -1.5 to 1.0 in the carbon oxidation state space. The shallower slope $(-0.5)$ compared to that $(-1)$ in Heald et al. (2010) hints at the possibility that the transition from less-oxidized OA (e.g., SVOOA) to more-oxidized OA (e.g, LVOOA) may occur via carboxylic acid formation with fragmentation of the carbon backbone (Ng et al., 2011). This analysis demonstrated the usefulness of the superimposed triangle-Van Krevelencarbon-oxidation-state (Tri-VK- $\overline{\mathrm{OS}}_{\mathrm{c}}$ ) space in evaluating the degree of oxygenation during the evolution of $\mathrm{OA}$. We use this method, along with individual indicators of $f_{44}, \mathrm{O}: \mathrm{C}$, and $\overline{\mathrm{OS}}_{\mathrm{c}}$ to evaluate the degree of oxygenation of $\mathrm{OA}$ in our study. Note that current analysis uses data from one observation site without considering the air mass history. Although the air masses during the three chosen periods were reasonably stable or well mixed, the actual evolution in OA characteristics may be complicated by other processes such as simple mixing during the transport of air masses.

During the hazy period $(\mathrm{H})$ of our campaign, the organics were the most oxygenated with average $f_{44}, \mathrm{O}: \mathrm{C}$, and $\overline{\mathrm{OS}}_{\mathrm{c}}$ of $0.15,0.51$, and -0.31 , respectively (Table 1 ). With little or no water in the particles (see below), the high solar irradiance (Fig. 1) and the high $\mathrm{O}_{\mathrm{x}}$ concentration associated with this high degree of oxygenation of OA suggest that gas-phase oxidation is probably the dominating process in the oxidation of organics. Recently, Wood et al. (2010) showed strong correlations between OA of secondary nature and $\mathrm{O}_{\mathrm{x}}$ in ground site measurements during periods of intense photochemistry. If the particles in $\mathrm{H}$ did exist as aqueous droplets, those particles would be highly concentrated supersaturated droplets because the average concentration of $\mathrm{PM}_{1}\left(32.3 \mu \mathrm{g} \mathrm{m}^{-3}\right)$ was almost twice as high as that of predicted $\mathrm{LWC}_{\mathrm{fp}}\left(17.5 \mu \mathrm{g} \mathrm{m}^{-3}\right.$, Table 1$)$. Therefore, even if aqueous-phase oxidation occurred during $\mathrm{H}$, it will be less important than gas-phase oxidation since liquid water content was likely too low to accommodate much of the precursor organics and oxidants. However, we do not rule out the possibility of other aqueous-phase processes such as polymerization that forms oligomers (Blando and Turpin, 2000). In the two foggy periods, the average $f_{44}$ were 0.13 and 0.14 , respectively, only slightly lower than that in the hazy period. The $\mathrm{O}: \mathrm{C}$ and $\overline{\mathrm{OS}}_{\mathrm{c}}$, however, were the highest in $\mathrm{H}$, followed by those in $\mathrm{F} 2$, and then those in F1, similar to the decreasing trend of $\mathrm{O}_{\mathrm{x}}$ concentration and the increasing trend of $\mathrm{LWC}_{\mathrm{fp}}$.

\subsubsection{The Tri-VK- $\overline{\mathrm{OS}}_{\mathrm{c}}$ space}

The $\mathrm{H}: \mathrm{C}$ and $\mathrm{O}: \mathrm{C}$ ratios of the OOA factors during the three chosen periods of this campaign are displayed in the Tri-VK- $\overline{\mathrm{OS}}_{\mathrm{c}}$ space in Fig. 3. The 3-day averages (the large blue, green, and red stars for F1, F2, and H, respectively) and 
Table 1. Measured and calculated parameters in three chosen periods (F1, F2, and H), and those in the overall and the non-foggy/non-hazy ("other") period.

\begin{tabular}{lccccc}
\hline & Overall $^{\mathrm{a}}$ & $\mathrm{F}^{\mathrm{b}}$ & $\mathrm{F} 2^{\mathrm{b}}$ & $\mathrm{H}^{\mathrm{b}}$ & Other $^{\mathrm{c}}$ \\
\hline $\mathrm{RH}(\%)$ & $80.3 \pm 12.3$ & $89.2 \pm 6.4$ & $91.1 \pm 2.5$ & $66.6 \pm 14.3$ & $79.7 \pm 11.5$ \\
$T\left({ }^{\circ} \mathrm{C}\right)$ & $24.6 \pm 2.4$ & $22.7 \pm 1.3$ & $23.3 \pm 0.8$ & $26.2 \pm 2.2$ & $24.8 \pm 2.4$ \\
$\mathrm{CC}(\%)$ & $71.9 \pm 19.7$ & $89.7 \pm 5.0$ & $89.7 \pm 1.2$ & $43.3 \pm 17.8$ & $71.1 \pm 18.2$ \\
\hline $\mathrm{SO}_{4}^{2-}$ & $7.9 \pm 4.8$ & $13.7 \pm 2.4$ & $11.8 \pm 4.8$ & $15.4 \pm 6.0$ & $5.9 \pm 2.9$ \\
$\mathrm{NO}_{3}^{-}$ & $0.63 \pm 0.71$ & $1.4 \pm 0.95$ & $0.42 \pm 0.18$ & $1.14 \pm 0.74$ & $0.51 \pm 0.63$ \\
$\mathrm{NH}_{4}^{+}$ & $2.5 \pm 1.5$ & $4.5 \pm 0.6$ & $3.4 \pm 1.4$ & $4.7 \pm 1.7$ & $2.0 \pm 1.0$ \\
$\mathrm{Org}$ & $4.4 \pm 3.6$ & $6.2 \pm 2.0$ & $4.2 \pm 1.3$ & $11.0 \pm 6.6$ & $3.5 \pm 2.5$ \\
\hline $\mathrm{HOA}$ & $1.33 \pm 1.90$ & $1.99 \pm 1.50$ & $0.95 \pm 0.64$ & $4.18 \pm 4.04$ & $0.99 \pm 1.29$ \\
$\mathrm{SVOOA}^{2}$ & $0.85 \pm 0.73$ & $1.15 \pm 0.69$ & $0.54 \pm 0.40$ & $0.65 \pm 0.46$ & $0.87 \pm 0.76$ \\
$\mathrm{LVOOA}^{-}$ & $2.08 \pm 2.04$ & $2.95 \pm 1.22$ & $2.44 \pm 1.16$ & $6.29 \pm 2.94$ & $1.49 \pm 1.37$ \\
\hline $\mathrm{LWC}_{\mathrm{fp}}$ & $20.1 \pm 19.4$ & $58.7 \pm 23.3$ & $47.5 \pm 19.0$ & $17.5 \pm 10.3$ & $13.2 \pm 9.9$ \\
$\mathrm{IS}$ & $18.1 \pm 14.0$ & $9.1 \pm 5.4$ & $7.6 \pm 2.0$ & $35.0 \pm 20.1$ & $18.3 \pm 12.7$ \\
$\mathrm{pH}$ & $0.96 \pm 0.64$ & $0.98 \pm 0.15$ & $0.84 \pm 0.11$ & $0.54 \pm 0.19$ & $1.02 \pm 0.72$ \\
$\mathrm{NH}_{4, \mathrm{~m} / \mathrm{p}}$ & $0.82 \pm 0.09$ & $0.80 \pm 0.02$ & $0.76 \pm 0.03$ & $0.77 \pm 0.03$ & $0.83 \pm 0.09$ \\
$\mathrm{O}_{\mathrm{x}}$ & $45.8 \pm 23.1$ & $48.5 \pm 10.5$ & $59.4 \pm 13.0$ & $68.6 \pm 39.0$ & $41.5 \pm 20.5$ \\
\hline$f_{44}$ & $0.12 \pm 0.03$ & $0.13 \pm 0.02$ & $0.14 \pm 0.02$ & $0.15 \pm 0.02$ & $0.12 \pm 0.03$ \\
$\mathrm{O}: \mathrm{C}$ & $0.40 \pm 0.11$ & $0.41 \pm 0.08$ & $0.43 \pm 0.08$ & $0.51 \pm 0.08$ & $0.39 \pm 0.12$ \\
$\mathrm{OS}_{\mathrm{c}}$ & $-0.53 \pm 0.12$ & $-0.50 \pm 0.08$ & $-0.38 \pm 0.08$ & $-0.31 \pm 0.22$ & $-0.58 \pm 0.33$ \\
\hline $\mathrm{Av}$ & & & &
\end{tabular}

\footnotetext{
a Average of all data in the whole campaign.

${ }^{b}$ Average of data from foggy days (F1 and F2) and hazy days (H). F1: 28-30 April 2011; F2: 14-16 May 2011; H:

27-29 May 2011.

$\mathrm{c}$ average of data from non-foggy and non-hazy days RH: relative humidity;

$T$ : temperature; $\mathrm{CC}$ : cloud coverage; $\mathrm{SO}_{4}^{2-}, \mathrm{NO}_{3}^{-}, \mathrm{NH}_{4}^{+}$, and Org: sulfate, nitrate, ammonium, and organic mass concentrations $\left(\mu \mathrm{g} \mathrm{m}^{-3}\right)$; HOA, SVOOA, and LVOOA: mass concentrations $\left(\mu \mathrm{g} \mathrm{m}^{-3}\right)$ of hydrocarbon-like organic aerosols, semi-volatile oxygenated organic aerosols and low-volatility oxygenated organic aerosols; $\mathrm{LWC}_{\mathrm{fp}}$ : liquid water content in fine particles $\left(\mu \mathrm{g} \mathrm{m}^{-3}\right)$; IS: ionic strength $\left(\mathrm{mol} \mathrm{kg}^{-1}\right) ; \mathrm{pH}_{\mathrm{is}}$ : in situ $\mathrm{pH} ; \mathrm{NH}_{4, \mathrm{~m} / \mathrm{p}}:$ measured over predicted $\mathrm{NH}_{4} ; \mathrm{O}_{\mathrm{x}}$ : odd oxygen $\left(\mathrm{O}_{3}+\mathrm{NO}_{2}\right)$ in ppbv; $f_{44}$ : fraction of $m / z 44$ in organic mass spectra; $\mathrm{O}$ : C: oxygen-to-carbon elemental ratio: $\overline{\mathrm{OS}}_{\mathrm{c}}$ : carbon oxidation state $(\approx 2 \times \mathrm{O}: \mathrm{C}-\mathrm{H}: \mathrm{C})$.
}

the average of the whole campaign (the large black star) lie near the solid blue line, which indicates the lower boundary of the transformed triangle space. Most of the data points lie between -1.5 and 0.5 in terms of $\overline{\mathrm{OS}}_{\mathrm{c}}$ values. Scattered data points obtained in F1 and F2 (blue triangles and green circles, respectively, in Fig. 3) deviate significantly from those obtained in $\mathrm{H}$ (red squares) towards the origin, indicating substantial differences in the chemical processes in periods $\mathrm{F} 1$ and $\mathrm{F} 2$ from those in period $\mathrm{H}$. Moving from $\mathrm{F} 1$ to $\mathrm{F} 2$ and then to $\mathrm{H}$, the average $\mathrm{O}: \mathrm{C}$ ratio increased. This observation is consistent with the increase in the LVOOA fraction moving from F1 to F2 and then to H shown in Fig. 2.

It is shown in Fig. 2 that during the $\mathrm{H}$ period when gasphase oxidation prevailed, the average LVOOA fraction was the highest, while the SVOOA fraction was the lowest. In fact, the average concentration of SVOOA during $\mathrm{H}$ was only slightly higher than that during F2, and was even lower than that during F1 (Table 1). The fact that the mass loading of aerosols (both inorganic and organic) during $\mathrm{H}$ was the highest seems to contradict the partitioning behavior that the more absorbing materials there are, the more favorable it is for the condensation of semi-volatile species (Pankow, 1994; Shilling et al., 2009), e.g., SVOOA. However, the overwhelmingly dominating fraction of LVOOA $(\sim 60 \%$ on average) suggests that multi-generation oxidation $(\mathrm{Ng}$ et al., 2006; Li et al., 2011a) may convert most of the "fresh" SOA, which was most likely SVOOA, to more "aged" LVOOA under the highly oxidative condition during the $\mathrm{H}$ period. On the other hand, as another important factor in organic partitioning, the average temperature in the $\mathrm{H}$ period was $2-3^{\circ} \mathrm{C}$ higher than in the F1 and F2 periods, which favors the evaporation of semi-volatile species such as SVOOA.

The slope of a fitted line can be used to infer the composition of OA and the chemical processes in OA formation (Heald et al., 2010; $\mathrm{Ng}$ et al., 2011). For the hazy period $\mathrm{H}$, a slope of -0.82 , the shallowest in the three chosen periods, was obtained (Fig. 3) from fitting the $10 \mathrm{~min}$ data. The slope is between -0.5 ( $\mathrm{Ng}$ et al., 2011) and -1 (Heald et al., 2010), and suggests that carboxylic acid formation with fragmentation and without fragmentation are both important processes during this hazy period. A similar slope of higher than $-1(-0.8)$ was also observed in Mexico City during the 


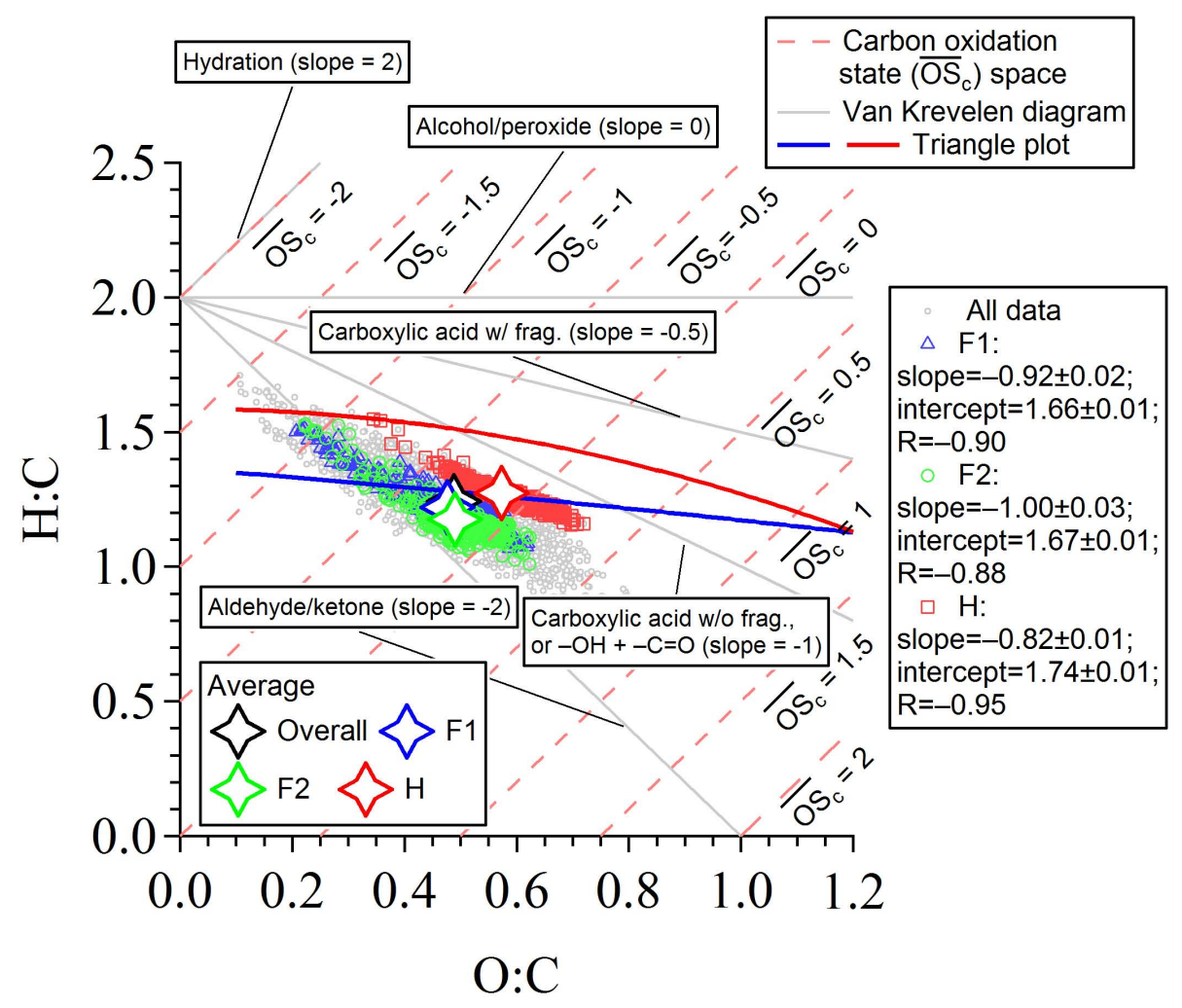

Fig. 3. The triangle-Van Krevelen- $\overline{\mathrm{OS}}_{\mathrm{c}}\left(\mathrm{Tri}-\mathrm{VK}-\overline{\mathrm{OS}}_{\mathrm{c}}\right)$ space with ambient data (10 min time resolution) for the OOA factors. Blue data points are for F1, green for F2, and red for $\mathrm{H}$. The black star represents the average in the whole campaign and the blue, green, and red stars represent those in $\mathrm{F} 1, \mathrm{~F} 2$, and $\mathrm{H}$, respectively.

Table 2. Fitted parameters of the plot (Fig. 4) of $\overline{\mathrm{OS}}_{\mathrm{c}}$ versus $f_{44}$ in different periods.

\begin{tabular}{lcccc}
\hline & Slope & Intercept & $r^{\mathrm{a}}$ & $N^{\mathrm{b}}$ \\
\hline Overall & $9.5 \pm 0.1$ & $-1.71 \pm 0.01$ & 0.89 & 4724 \\
F1 & $12.0 \pm 0.2$ & $-2.10 \pm 0.03$ & 0.96 & 393 \\
F2 & $10.5 \pm 0.3$ & $-1.81 \pm 0.04$ & 0.90 & 337 \\
H & $11.9 \pm 0.2$ & $-2.08 \pm 0.03$ & 0.94 & 395 \\
F1 + F2 + H & $11.4 \pm 0.1$ & $-1.99 \pm 0.02$ & 0.93 & 1125 \\
Others & $9.3 \pm 0.1$ & $-1.68 \pm 0.01$ & 0.88 & 3599 \\
\hline
\end{tabular}

${ }^{\mathrm{a}}$ Pearson's $r$; ${ }^{\mathrm{b}}$ number of data points.

MILAGRO campaign at high oxidation levels, which was attributed to fragmentation with $\mathrm{C}-\mathrm{C}$ bond cleavage that led to increases in $\mathrm{O}: \mathrm{C}$ but relatively small changes in $\mathrm{H}: \mathrm{C}$ (Heald et al., 2010). This similarity of slopes in our hazy period and the high-oxidation-level period in MILAGRO further suggests that gas-phase oxidation likely has prevailed during the hazy days, similar to the high photochemical aging period in MILAGRO. For F1 and F2, the slopes were -0.92 and -1.00 , respectively. At first glance, the similar slopes may suggest that the same mechanisms were behind the increases in the degree of oxygenation in the two foggy periods. However, this may not be the case, as will be explained in Section 3.3 when we analyze the data with $\mathrm{O}_{\mathrm{x}}$ concentrations and $\mathrm{LWC}_{\mathrm{fp}}$. The intercepts for all three periods were at 1.66-1.74, somewhat lower than the intercept of $2.0(\mathrm{O}: \mathrm{C}=0$ and $\mathrm{H}: \mathrm{C}=2)$ of the best-fit line in the work of Heald et al. (2010), which assumed SOA precursors of alkenes (only one $\mathrm{C}=\mathrm{C}$ double bond), cycloalkanes, or arbitrarily long acyclic alkanes. The lower $\mathrm{H}: \mathrm{C}$ ratios in our study that resulted in a lower intercept than 2.0 suggest that the precursors of SOA at our site were probably dominated by high-order unsaturated/cyclic (number of $\mathrm{C}=\mathrm{C}$ double bond or ring structure, i.e., double bond equivalency $>1$ ) volatile organic compounds (VOCs) such as light aromatics (e.g., toluene) and biogenic VOCs, which have $\mathrm{H}$ : $\mathrm{C}$ ratios of 1.1-1.6, rather than simple alkenes, cycloalkanes, or long acyclic alkanes. This inference of SOA precursors is consistent with a previous tracer-based study (Hu et al., 2008) that concluded that biogenic VOCs and toluene (or broadly light aromatics) are the major precursors of SOA at non-roadside sites in Hong Kong.

\subsubsection{Carbon oxidation state $\left(\overline{\mathrm{OS}}_{\mathrm{c}}\right)$}

A strong correlation between $\overline{\mathrm{OS}}_{\mathrm{c}}$ and $f_{44}$, as shown in Fig. $4 \mathrm{a}$ and $\mathrm{b}$, and Table 2, indicates that carboxylic groups 

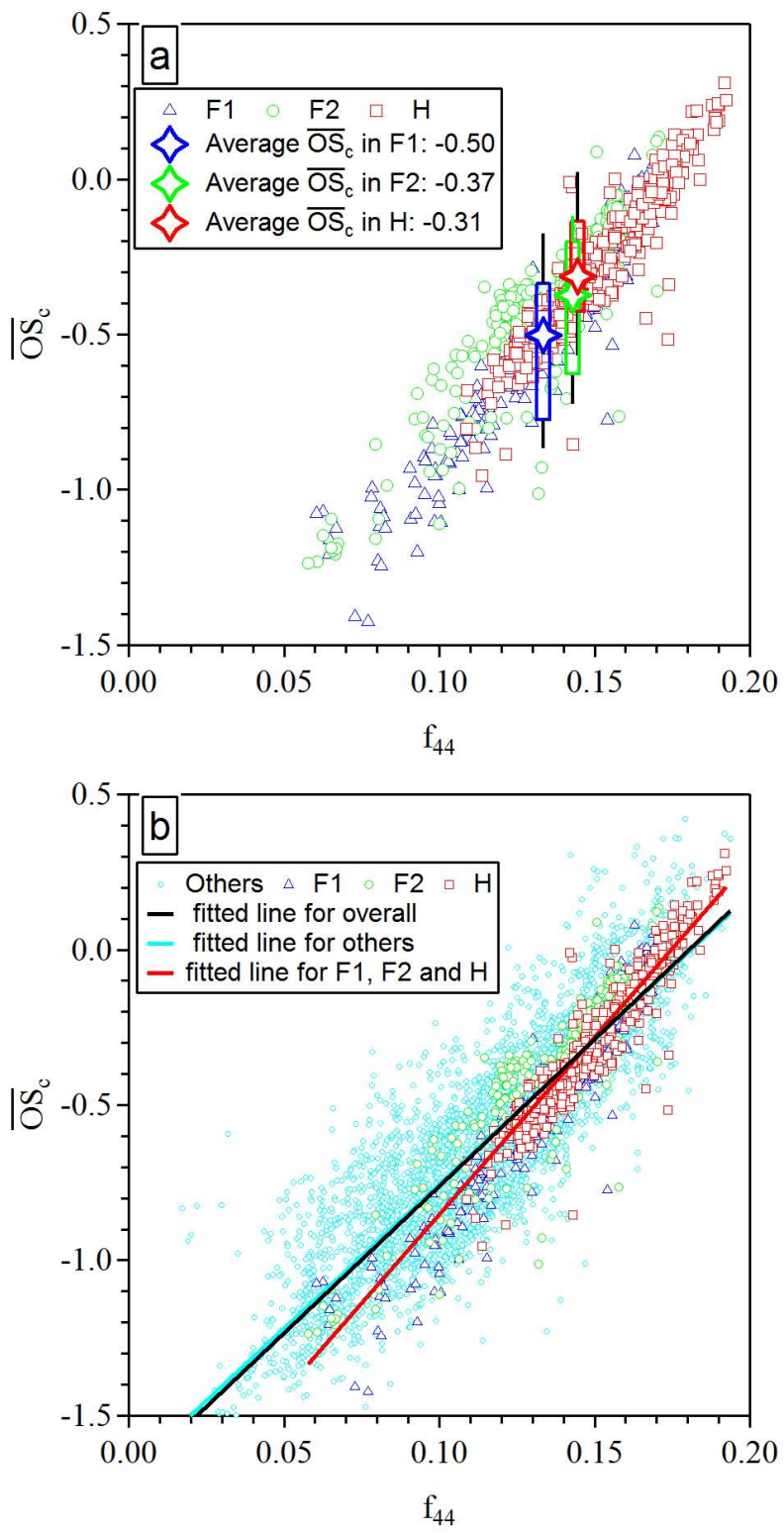

Fig. 4. (a) Carbon oxidation state $\left(\overline{\mathrm{OS}}_{\mathrm{c}}\right)$ vs. $m / z 44$ fraction in organic mass spectra $\left(f_{44}\right)$ in F1 (blue triangle), F2 (green circle), and $\mathrm{H}$ (red square) periods. The blue, green, and red stars show the average values of $\overline{\mathrm{OS}}_{\mathrm{c}}$ and $f_{44}$ in $\mathrm{F} 1, \mathrm{~F} 2$, and $\mathrm{H}$, respectively. The boxes and whiskers show the 25 th/75th and 10th/90th percentiles of the values of $\overline{\mathrm{OS}}_{\mathrm{c}}$ in each period, respectively. (b) Fitted lines of the $\overline{\mathrm{OS}}_{\mathrm{c}}$ vs. $f_{44}$ data for all data (black line), for all three chosen periods (F1, F2, and H) (red line), and for the "other" period (light blue line). See Table 2 for fitted parameters.

such as LVOOA, which can generate a large amount of $\mathrm{CO}_{2}^{+}$ ions, are the main reason for the high $\overline{\mathrm{OS}}_{\mathrm{c}}$ observed. The fitted line for the overall data has a slope of 9.5 and an intercept of -1.71 (Table 2), while those for the data points in $\mathrm{F} 1, \mathrm{~F} 2, \mathrm{H}$, and $\mathrm{F} 1+\mathrm{F} 2+\mathrm{H}$ have slopes of 10.5 to 12 and intercepts of -1.8 to -2.1 . The slopes suggest that an in- crease of 0.1 in $f_{44}$ in organics would result in an increase of $0.95-1.20 \mathrm{in} \overline{\mathrm{OS}}_{\mathrm{c}}$. The intercepts suggest that the non-acid moieties of the $\mathrm{OA}$ have an average $\overline{\mathrm{OS}}_{\mathrm{c}}$ of -1.7 to -2.1 . As shown in Table 2, the smaller slope (9.3) and less negative intercept $(-1.68)$ during the "other" period indicate less sensitivity of $\overline{\mathrm{OS}}_{\mathrm{c}}$ to $f_{44}$ and more abundant oxygenated nonacid moieties in the organics than during the chosen foggy or hazy periods. Therefore, the organics during the non-foggy and non-hazy periods may contain relatively more abundant oxygenated groups other than the carboxylic group, such as carbonyl and hydroxyl groups, than the three chosen periods. This is consistent with the high fraction of SVOOA in the "other" periods (Fig. 2). Those non-acid oxygenated groups may undergo further oxidation during their atmospheric lifetime if conditions permit.

As shown in Fig. 4a and Table 1, there are only slight increases in average $f_{44}$ moving from $\mathrm{F} 1$ to $\mathrm{F} 2$ and then to $\mathrm{H}$. The increases in average $\mathrm{O}: \mathrm{C}$ are slightly more obvious, as shown in Table 1 , but the increases in average $\overline{\mathrm{OS}}_{\mathrm{c}}$ are the most noticeable, as shown in Table 1 and Fig. 4a. While $f_{44}$ used a single UMR $m / z$ value (44, representing $\mathrm{CO}_{2}^{+}$) to indicate the degree of oxygenation of $\mathrm{OA}, \mathrm{O}: \mathrm{C}$ was computed using many high-resolution ions, and $\overline{\mathrm{OS}}_{\mathrm{c}}$ included both $\mathrm{O}: \mathrm{C}$ and $\mathrm{H}: \mathrm{C}$ to represent the overall carbon oxidation state. This observation indicates that $\overline{\mathrm{OS}}_{\mathrm{c}}$ might better reflect the overall degree of oxygenation of OA, especially when a larger fraction of non-acid organics such as SVOOA is present.

\subsection{LVOOA and SVOOA}

The mass fractions of LVOOA vs. those of SVOOA in the three periods, color-coded according to $\mathrm{O}_{\mathrm{x}}$ concentration, are shown in Fig. 5. The gray symbols represent all the data points and they show a boomerang-shaped distribution in these $\log -\log$ plots because of the low HOA fraction $(\sim 0.3$, Fig. 2). For F1 (color symbols in Fig. 5a), the distribution spreads on the two winglets with a few data points having an SVOOA fraction of 0.5 and larger, suggesting that LVOOA and, to a lesser extent, SVOOA contributed substantially to the total OA during this period. A large SVOOA fraction is associated with a low $\mathrm{O}_{\mathrm{x}}$ concentration. For F2 (color symbols Fig. 5b), more data points shifted towards the upper winglet (except for a few data points with relatively low SVOOA and LVOOA fractions, which was due to higher HOA fraction), indicating a smaller SVOOA fraction than in F1, consistent with the average fractions in Fig. 2. Again, the relatively large SVOOA fraction in F2 was associated with a low $\mathrm{O}_{\mathrm{x}}$ concentration as in F1. Finally, LVOOA was dominant during the hazy period (Fig. $5 \mathrm{c}$ ), which saw a high $\mathrm{O}_{\mathrm{x}}$ concentration.

The mass fractions and concentrations of LVOOA and SVOOA in the $\mathrm{F} 1$ and $\mathrm{F} 2$ periods as a function of $\mathrm{O}_{\mathrm{x}}$ concentration and color-coded according to $\mathrm{LWC}_{\mathrm{fp}}$ are shown in Fig. 6. $\mathrm{LWC}_{\mathrm{fp}}$ was low in $\mathrm{H}$ and therefore $\mathrm{H}$ is not 


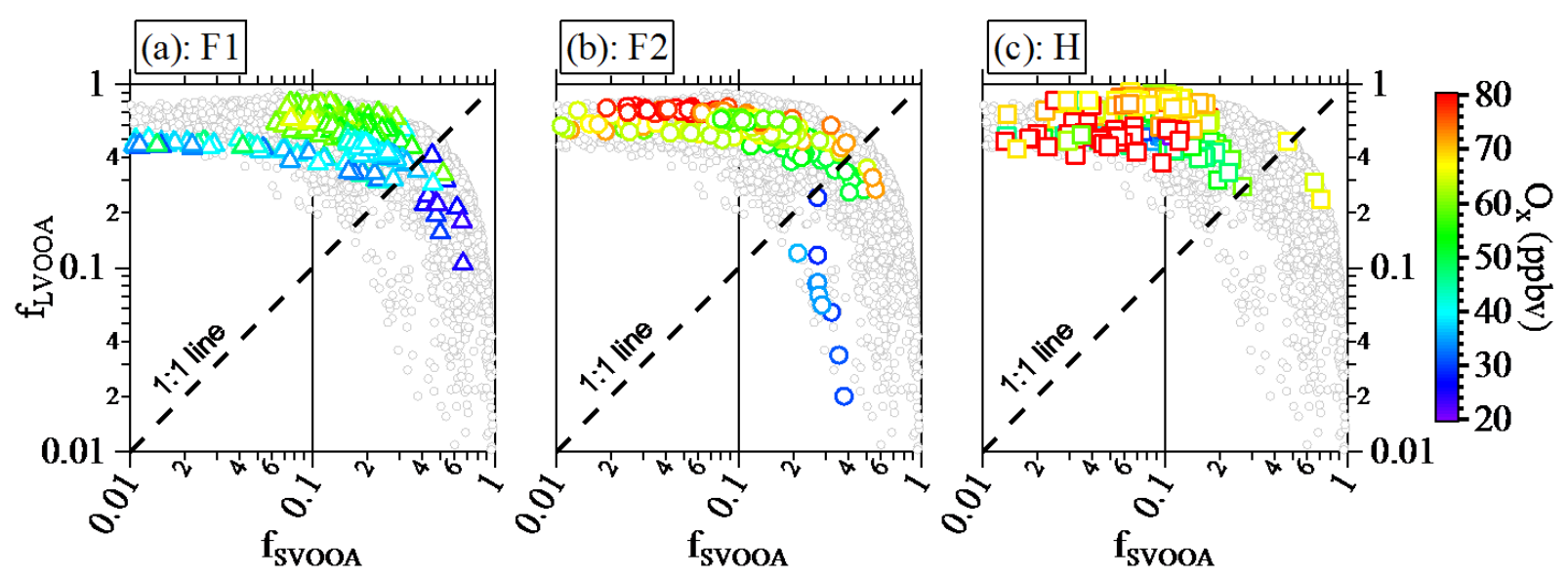

Fig. 5. Averaged mass fraction of LVOOA vs. averaged mass fraction of SVOOA in F1 (a), F2 (b), and $\mathrm{H}$ (c), color-coded according to $\mathrm{O}_{\mathrm{x}}$ concentration. The gray symbols in each panel represent all data points.

included in this comparison. The fractions and concentrations of LVOOA and SVOOA show less linear relationships with $\mathrm{O}_{\mathrm{x}}$ concentration in $\mathrm{F} 1$ (Fig. 6a-d) than in F2 (Fig. 6eh). For F2, LVOOA fractions and concentrations increased, while SVOOA fractions and concentrations decreased as $\mathrm{O}_{\mathrm{x}}$ concentration increased. This observation suggests that oxidation, either in the gas phase or in the particle phase, converted the SVOOA to LVOOA. Given the low photochemical activity in the foggy period F2 (Fig. 1a), gas-phase oxidation is expected to be relatively less efficient than in other periods such as H. Therefore, the oxidation in the particle phase, and even more likely in the aqueous phase, was likely to have converted the SVOOA to LVOOA, although gas-phase oxidation may also have contributed partly. The OOA factors, especially SVOOA, show a lower dependence on $\mathrm{O}_{\mathrm{x}}$ concentration in F1 than in F2. In Fig. 6b, where SVOOA fraction vs. $\mathrm{O}_{\mathrm{x}}$ concentration is plotted and color-coded according to $\mathrm{LWC}_{\mathrm{fp}}$, the data points are segregated into low-, mid-, and high- $\mathrm{LWC}_{\mathrm{fp}}$ regions. The mid- $-\mathrm{WC}_{\mathrm{fp}}$ region contains the highest SVOOA fractions, with $\mathrm{O}_{\mathrm{x}}$ concentration falling in the range of $20-60 \mathrm{ppbv}$. This suggests a possibility of enhanced partitioning of SVOOA with medium to high levels of $\mathrm{LWC}_{\mathrm{fp}}$, as proposed by Pankow et al. (2010). In the high- $\mathrm{LWC}_{\mathrm{fp}}$ region, the SVOOA fraction was not the highest, probably because of the even more efficient partitioning of LVOOA as shown in Fig. 6a. The above comparison suggests that in the foggy period F1 partitioning might play an important role, whereas in the foggy period F2 oxidation (more likely in aqueous phase) might have played a more important role in incorporating OOA into the particle phase.

\subsubsection{Effects of particle characteristics $\left(\mathrm{pH}_{\mathrm{is}}, \mathrm{IS}\right.$, and $\mathbf{L W C}_{\mathbf{f p}}$ )}

The correlations of the degree of oxygenation of OA with IS and $\mathrm{pH}_{\mathrm{is}}$ in $\mathrm{F} 1$ and $\mathrm{F} 2$ are shown in Fig. 7. As shown in previous sections, the oxidative capacity (represented by $\mathrm{O}_{\mathrm{x}}$

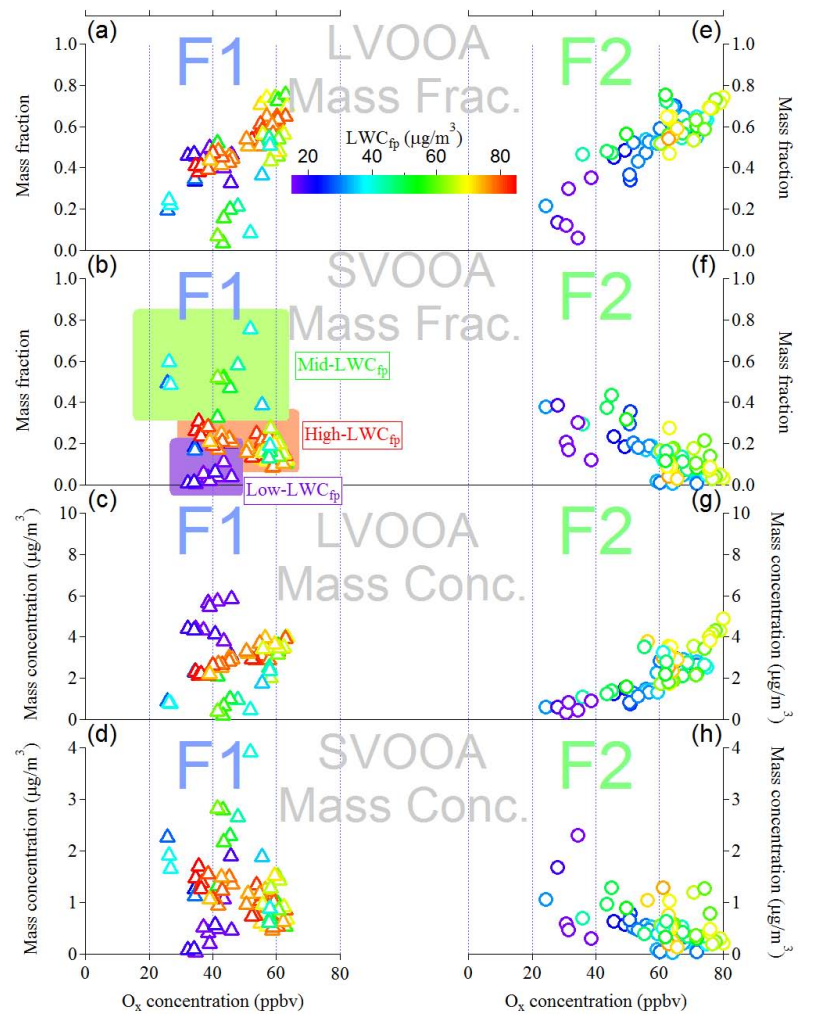

Fig. 6. Hourly averaged mass fractions of LVOOA (a), mass fraction of SVOOA (b), mass concentration of LVOOA (c), and mass concentration of SVOOA (d) in $\mathrm{F} 1$ vs. $\mathrm{O}_{\mathrm{x}}$ concentration. Mass fractions of LVOOA (e), mass fraction of SVOOA (f), mass concentration of LVOOA (g), and mass concentration of SVOOA (h) in F2 vs. $\mathrm{O}_{\mathrm{x}}$ concentration. 

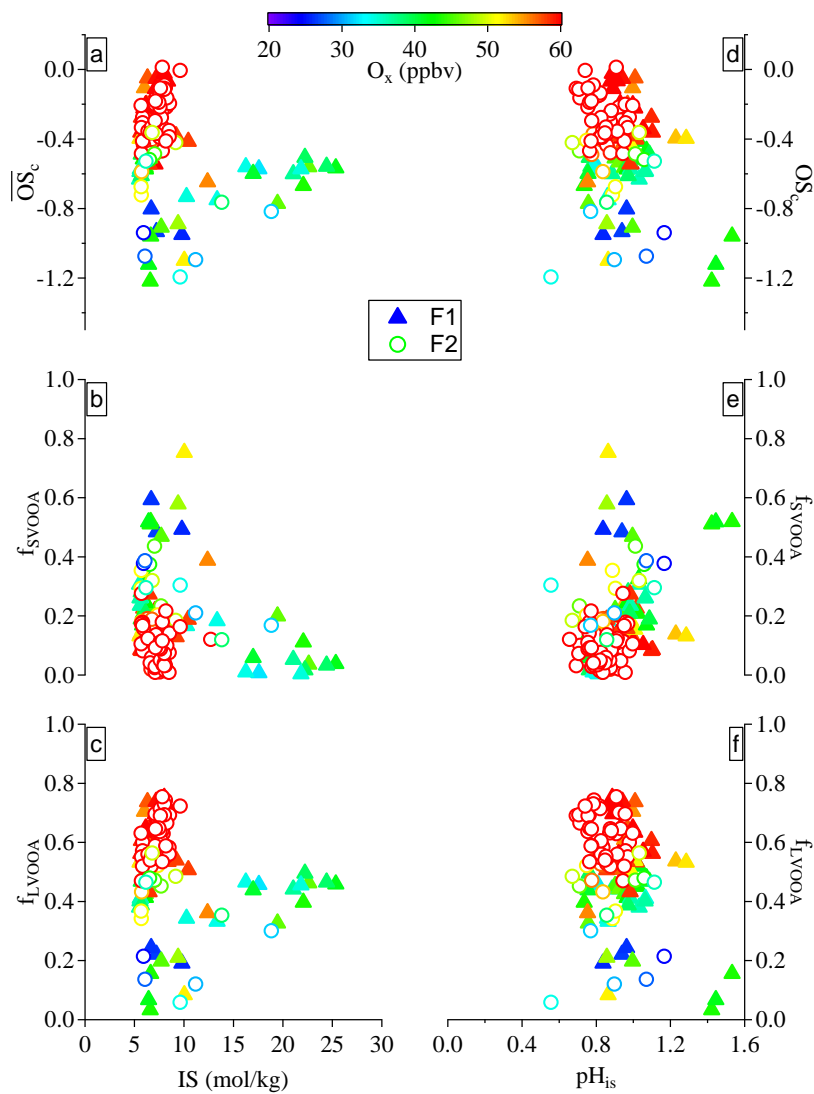

Fig. 7. Hourly averaged carbon oxidation state $\left(\overline{\mathrm{OS}}_{\mathrm{c}}\right)$ (a), SVOOA fraction $\left(f_{\text {SVOOA }}\right)$ (b), and LVOOA fraction $\left(f_{\text {LVOOA }}\right)$ (c) for F1 (blue solid triangles) and F2 (green open circles) plotted against estimated ionic strength (IS). Carbon oxidation state $\left(\overline{\mathrm{OS}}_{\mathrm{c}}\right)(\mathbf{d})$, SVOOA fraction $\left(f_{\text {SVOOA }}\right)$ (e), and LVOOA fraction $\left(f_{\text {LVOOA }}\right)$ (f) for F1 (blue solid triangles) and F2 (green open circles) plotted against estimated fine-particle in situ $\mathrm{pH}\left(\mathrm{pH}_{\mathrm{is}}\right)$. Data points are color-coded according to $\mathrm{O}_{\mathrm{x}}$ concentration.

concentration) was the major reason for the high $\overline{\mathrm{OS}}_{\mathrm{c}}$ observed in F2. In contrast, low $\mathrm{O}_{\mathrm{x}}$ concentrations prevailed in $\mathrm{F} 1$, and the $\overline{\mathrm{OS}}_{\mathrm{c}}$ shows a correlation with IS in this period, as shown in Fig. 7a. The fraction of SVOOA for those data points with low $\mathrm{O}_{\mathrm{x}}$ concentrations decreased as IS increased (Fig. 7b), while the opposite is true for the fraction of LVOOA (Fig. 7c). The high ionic strength may favor the dissolution of the more oxygenated fraction of LVOOA in comparison to SVOOA. A similar, but less obvious, trend of an increasing LVOOA fraction and a decreasing SVOOA fraction with increasing IS during the whole campaign is shown in Fig. S3. The correlations of $\overline{\mathrm{OS}}_{\mathrm{c}}, f_{\mathrm{SVOOA}}$, and $f_{\mathrm{LVOOA}}$ with $\mathrm{pH}_{\text {is }}$ are much less obvious for $\mathrm{F} 1$ and $\mathrm{F} 2$ (Fig. 7d, $\mathrm{e}$, and $\mathrm{f}$, respectively). But the correlations of $f_{\text {SVOOA }}$ and $f_{\text {LVOOA }}$ with $\mathrm{pH}_{\text {is }}$ for the whole campaign are more obvious with decreasing $f_{\text {SVOOA }}$ and increasing $f_{\text {LVOOA }}$ as the $\mathrm{pH}_{\text {is }}$ decreased (Fig. S3). A similar trend is seen for F1 as shown in Fig. $7 \mathrm{e}$ and $\mathrm{f}$ (solid triangles), but to a much smaller extent.
For most of $\mathrm{F} 2$, the $\mathrm{O}_{\mathrm{x}}$ concentrations exceeded $50 \mathrm{ppbv}$ and the particle characteristics $\left(\mathrm{pH}_{\mathrm{is}}\right.$, IS, and $\left.\mathrm{LWC}_{\mathrm{fp}}\right)$ showed weak correlations with the degree of oxygenation of OA. Oxidation, most likely in the aqueous phase, is the major reason for the high $\overline{\mathrm{OS}}_{\mathrm{c}}$ observed, which is reflected by the high LVOOA fraction observed in F2. In F1, however, the $\mathrm{O}_{\mathrm{x}}$ concentrations were relatively low most of the time, and gasphase oxidation was not effective. Both physical partitioning (including dissolution) and aqueous-phase oxidation may be affected by particle characteristics $\left(\mathrm{pH}_{\mathrm{is}}\right.$, IS, and $\mathrm{LWC}_{\mathrm{fp}}$ ). Dissolution may be influenced by salting-in and salting-out effects, and the influence seems to be different for SVOOA and LVOOA. As for aqueous-phase oxidation, it has been shown that OOA production, especially SVOOA, in F1 depended less on $\mathrm{O}_{\mathrm{x}}$ concentration (Fig. 6). Hence, physical partitioning may be more important than chemical oxidation in incorporating the OOA into the particle phase in $\mathrm{F} 1$.

Overall, the processes that are responsible for the high degree of oxygenation in F1 and F2 are different although these two periods shared a similar slope and intercept in the Van Krevelen diagram (Fig. 3). In the period F1, OOA formation showed a stronger correlation with particle characteristics $\left(\mathrm{pH}_{\mathrm{is}}\right.$, IS, and $\mathrm{LWC}_{\mathrm{fp}}$ ) such as IS and in situ $\mathrm{pH}$, while that in the period $\mathrm{F} 2$ had a stronger dependence on $\mathrm{O}_{\mathrm{x}}$ concentration.

\section{Conclusion}

The present study examines chemical properties of organic aerosols during springtime in Hong Kong, with a focus on two foggy periods and one hazy period. Results showed that NR-PM $\mathrm{P}_{1}$ concentrations were higher during the foggy (F1 and F2) and the hazy period (H) than during the nonfoggy/non-hazy or "other" periods (Table 1 and Figs. S2 and 2). Gas-phase oxidation during the hazy period was likely the main driving force for organic oxidation, while aqueous-phase processes may have been responsible for the high degree of oxygenation of OA during the foggy periods. Different mechanisms in OA formation between the foggy periods and the hazy period are reflected by very different slopes in the Tri-VK- $\overline{\mathrm{OS}}_{\mathrm{c}}$ space (Fig. 2). Although F1 and F2 saw similar slopes in the Tri-VK- $\overline{\mathrm{OS}}_{\mathrm{c}}$ space, the processes for $\mathrm{OA}$ formation in these two foggy periods are believed to be different. In F1, OOA, especially SVOOA, showed a weaker dependence on $\mathrm{O}_{\mathrm{x}}$ concentration, but a stronger correlation with particle characteristics $\left(\mathrm{pH}_{\mathrm{is}}\right.$, IS, and $\left.\mathrm{LWC}_{\mathrm{fp}}\right)$ such as IS and $\mathrm{pH}_{\text {is }}$ than those in F2. This suggests that in F1 partitioning (including dissolution) may play a big role in the incorporation of oxygenated OA into the particle phase. OOA in $\mathrm{F} 2$ showed a stronger dependence on $\mathrm{O}_{\mathrm{x}}$ concentration, with SVOOA decreased but LVOOA increased with increasing $\mathrm{O}_{\mathrm{x}}$ concentration. This indicates a conversion of SVOOA to LVOOA by oxidation, most likely in particle phase, due 
to low photochemical activity, although gas-phase oxidation may also have played a part.

To date, it is still difficult to differentiate the contribution of gas-phase oxidation from that of aqueous-phase oxidation in OOA formation. Nevertheless, the current study suggests that a high degree of oxygenation of OA can result even if the photochemical activities during foggy days are relatively low. Furthermore, the comparison in this study demonstrates that the behavior of OA formation can be quite different even for periods with similarly high liquid water contents in fine particles. Finally, the foggy periods F1 and F2 also saw high percentages of cloud cover (Table 1), which normally coexist with high liquid water contents in fine particles and likely have played a part in the oxidation of OA in cloud water. However, more investigation is needed to further differentiate between the contribution of OA oxidation in cloud droplets and that in wet aerosol particles.

\section{Supplementary material related to this article is available online at: http://www.atmos-chem-phys.net/13/ 8739/2013/acp-13-8739-2013-supplement.pdf.}

Acknowledgements. This work was supported by the University Grants Committee (Special Equipment Grant, SEG-HKUST07), the Environmental Conservation Fund of Hong Kong (project no. ECWW09EG04), and the Research Grants Council of the Hong Kong Special Administrative Region, China (project no. 600413).

Edited by: B. Ervens

\section{References}

Aiken, A. C., DeCarlo, P. F., and Jimenez, J. L.: Elemental analysis of organic species with electron ionization high-resolution mass spectrometry, Anal. Chem., 79, 8350-8358, 2007.

Aiken, A. C., Decarlo, P. F., Kroll, J. H., Worsnop, D. R., Huffman, J. A., Docherty, K. S., Ulbrich, I. M., Mohr, C., Kimmel, J. R., Sueper, D., Sun, Y., Zhang, Q., Trimborn, A., Northway, M., Ziemann, P. J., Canagaratna, M. R., Onasch, T. B., Alfarra, M. R., Prevot, A. S. H., Dommen, J., Duplissy, J., Metzger, A., Baltensperger, U., and Jimenez, J. L.: O/C and OM/OC ratios of primary, secondary, and ambient organic aerosols with high-resolution time-of-flight aerosol mass spectrometry, Environ. Sci. Technol., 42, 4478-4485, 2008.

Aiken, A. C., Salcedo, D., Cubison, M. J., Huffman, J. A., DeCarlo, P. F., Ulbrich, I. M., Docherty, K. S., Sueper, D., Kimmel, J. R., Worsnop, D. R., Trimborn, A., Northway, M., Stone, E. A., Schauer, J. J., Volkamer, R. M., Fortner, E., de Foy, B., Wang, J., Laskin, A., Shutthanandan, V., Zheng, J., Zhang, R., Gaffney, J., Marley, N. A., Paredes-Miranda, G., Arnott, W. P., Molina, L. T., Sosa, G., and Jimenez, J. L.: Mexico City aerosol analysis during MILAGRO using high resolution aerosol mass spectrometry at the urban supersite (T0) - Part 1: Fine particle composition and organic source apportionment, Atmos. Chem. Phys., 9, 6633-6653, doi:10.5194/acp-9-6633-2009, 2009.
Alfarra, M. R., Prevot, A. S. H., Szidat, S., Sandradewi, J., Weimer, S., Lanz, V. A., Schreiber, D., Mohr, M., and Baltensperger, U.: Identification of the mass spectral signature of organic aerosols from wood burning emissions, Environ. Sci. Technol., 41, 57705777, 2007.

Allan, J. D., Alfarra, M. R., Bower, K. N., Williams, P. I., Gallagher, M. W., Jimenez, J. L., McDonald, A. G., Nemitz, E., Canagaratna, M. R., Jayne, J. T., Coe, H., and Worsnop, D. R.: Quantitative sampling using an Aerodyne aerosol mass spectrometer - 2. Measurements of fine particulate chemical composition in two U.K. cities, J. Geophys. Res.-Atmos., 108, 4091, doi:10.1029/2002jd002359, 2003.

Allan, J. D., Delia, A. E., Coe, H., Bower, K. N., Alfarra, M. R., Jimenez, J. L., Middlebrook, A. M., Drewnick, F., Onasch, T. B., Canagaratna, M. R., Jayne, J. T., and Worsnop, D. R.: A generalised method for the extraction of chemically resolved mass spectra from aerodyne aerosol mass spectrometer data, J. Aerosol Sci., 35, 909-922, 2004.

Blando, J. D. and Turpin, B. J.: Secondary organic aerosol formation in cloud and fog droplets: A literature evaluation of plausibility, Atmos. Environ., 34, 1623-1632, 2000.

Chan, M. N., Kreidenweis, S. M., and Chan, C. K.: Measurements of the hygroscopic and deliquescence properties of organic compounds of different solubilities in water and their relationship with cloud condensation nuclei activities, Environ. Sci. Technol., 42, 3602-3608, 2008.

Chang, R. Y.-W., Slowik, J. G., Shantz, N. C., Vlasenko, A., Liggio, J., Sjostedt, S. J., Leaitch, W. R., and Abbatt, J. P. D.: The hygroscopicity parameter $(\kappa)$ of ambient organic aerosol at a field site subject to biogenic and anthropogenic influences: relationship to degree of aerosol oxidation, Atmos. Chem. Phys., 10, 5047-5064, doi:10.5194/acp-10-5047-2010, 2010.

Clegg, S. L., Brimblecombe, P., and Wexler, A. S.: Thermodynamic model of the system $\mathrm{H}^{+}-\mathrm{NH}_{4}^{+}-\mathrm{SO}_{4}^{2-}-\mathrm{NO}^{3-}-\mathrm{H}_{2} \mathrm{O}$ at tropospheric temperatures, J. Phys. Chem. A, 102, 2137-2154, 1998.

Dall'Osto, M., Harrison, R. M., Coe, H., and Williams, P.: Real-time secondary aerosol formation during a fog event in London, Atmos. Chem. Phys., 9, 2459-2469, doi:10.5194/acp-9-2459-2009, 2009.

DeCarlo, P. F., Slowik, J. G., Worsnop, D. R., Davidovits, P., and Jimenez, J. L.: Particle morphology and density characterization by combined mobility and aerodynamic diameter measurements. Part 1: Theory, Aerosol Sci. Technol., 38, 1185-1205, 2004.

DeCarlo, P. F., Kimmel, J. R., Trimborn, A., Northway, M. J., Jayne, J. T., Aiken, A. C., Gonin, M., Fuhrer, K., Horvath, T., Docherty, K. S., Worsnop, D. R., and Jimenez, J. L.: Field-deployable, high-resolution, time-of-flight aerosol mass spectrometer, Anal. Chem., 78, 8281-8289, 2006.

Duplissy, J., DeCarlo, P. F., Dommen, J., Alfarra, M. R., Metzger, A., Barmpadimos, I., Prevot, A. S. H., Weingartner, E., Tritscher, T., Gysel, M., Aiken, A. C., Jimenez, J. L., Canagaratna, M. R., Worsnop, D. R., Collins, D. R., Tomlinson, J., and Baltensperger, U.: Relating hygroscopicity and composition of organic aerosol particulate matter, Atmos. Chem. Phys., 11, 11551165, doi:10.5194/acp-11-1155-2011, 2011.

Ervens, B., Turpin, B. J., and Weber, R. J.: Secondary organic aerosol formation in cloud droplets and aqueous particles (aqSOA): a review of laboratory, field and model stud- 
ies, Atmos. Chem. Phys., 11, 11069-11102, doi:10.5194/acp-1111069-2011, 2011.

Fang, M., Zheng, M., Wang, F., Chim, K. S., and Kot, S. C.: The long-range transport of aerosols from northern China to Hong Kong - a multi-technique study, Atmos. Environ., 33, 18031817, 1999.

Farmer, D. K., Matsunaga, A., Docherty, K. S., Surratt, J. D., Seinfeld, J. H., Ziemann, P. J., and Jimenez, J. L.: Response of an aerosol mass spectrometer to organonitrates and organosulfates and implications for atmospheric chemistry, P. Natl. Acad. Sci. USA, 107, 6670-6675, 2010.

Frosch, M., Bilde, M., DeCarlo, P. F., Juranyi, Z., Tritscher, T., Dommen, J., Donahue, N. M., Gysel, M., Weingartner, E., and Baltensperger, U.: Relating cloud condensation nuclei activity and oxidation level of alpha-pinene secondary organic aerosols, J. Geophys. Res.-Atmos., 116, D22212, doi:10.1029/2011jd016401, 2011.

Ge, X., Zhang, Q., Sun, Y., Ruehl, C. R., and Setyan, A.: Effect of aqueous-phase processing on aerosol chemistry and size distributions in Fresno, California, during wintertime, Environ. Chem., 9, 221-235, 2012.

Hallquist, M., Wenger, J. C., Baltensperger, U., Rudich, Y., Simpson, D., Claeys, M., Dommen, J., Donahue, N. M., George, C., Goldstein, A. H., Hamilton, J. F., Herrmann, H., Hoffmann, T., Iinuma, Y., Jang, M., Jenkin, M. E., Jimenez, J. L., Kiendler-Scharr, A., Maenhaut, W., McFiggans, G., Mentel, Th. F., Monod, A., Prévôt, A. S. H., Seinfeld, J. H., Surratt, J. D., Szmigielski, R., and Wildt, J.: The formation, properties and impact of secondary organic aerosol: current and emerging issues, Atmos. Chem. Phys., 9, 5155-5236, doi:10.5194/acp-9-51552009, 2009.

Heald, C. L., Kroll, J. H., Jimenez, J. L., Docherty, K. S., DeCarlo, P. F., Aiken, A. C., Chen, Q., Martin, S. T., Farmer, D. K., and Artaxo, P.: A simplified description of the evolution of organic aerosol composition in the atmosphere, Geophys. Res. Lett., 37, L08803, doi:10.1029/2010g1042737, 2010.

Hennigan, C. J., Bergin, M. H., Dibb, J. E., and Weber, R. J.: Enhanced secondary organic aerosol formation due to water uptake by fine particles, Geophys. Res. Lett., 35, L18801, doi:10.1029/2008GL035046, 2008.

Hennigan, C. J., Bergin, M. H., Russell, A. G., Nenes, A., and Weber, R. J.: Gas/particle partitioning of water-soluble organic aerosol in Atlanta, Atmos. Chem. Phys., 9, 3613-3628, doi:10.5194/acp-9-3613-2009, 2009.

Herckes, P., Hannigan, M. P., Trenary, L., Lee, T., and Collett, J. L.: Organic compounds in radiation fogs in Davis (California), Atmos. Res., 64, 99-108, 2002.

Hersey, S. P., Craven, J. S., Schilling, K. A., Metcalf, A. R., Sorooshian, A., Chan, M. N., Flagan, R. C., and Seinfeld, J. H.: The Pasadena Aerosol Characterization Observatory (PACO): chemical and physical analysis of the Western Los Angeles basin aerosol, Atmos. Chem. Phys., 11, 7417-7443, doi:10.5194/acp11-7417-2011, 2011.

Ho, P. Y.: Weathering the storm: Hong Kong Observatory and Social Development, Hong Kong University Press, Hong Kong, 2003.

Hu, D., Bian, Q., Li, T. W. Y., Lau, A. K. H., and Yu, J. Z.: Contributions of isoprene, monoterpenes, beta-caryophyllene, and toluene to secondary organic aerosols in Hong Kong during the summer of 2006, J. Geophys. Res.-Atmos., 113, D22206,
doi:10.1029/2008JD010437, 2008.

Huang, X. F. and Yu, J. Z.: Is vehicle exhaust a significant primary source of oxalic acid in ambient aerosols?, Geophys. Res. Lett., 34, L02808, doi:10.1029/2006gl028457, 2007.

Huang, X. H. H., Ip, H. S. S., and Yu, J. Z.: Secondary organic aerosol formation from ethylene in the urban atmosphere of Hong Kong: A multiphase chemical modeling study, J. Geophys. Res.-Atmos., 116, D03206, doi:10.1029/2010JD014121, 2011.

Jimenez, J. L., Canagaratna, M. R., Donahue, N. M., Prevot, A. S. H., Zhang, Q., Kroll, J. H., DeCarlo, P. F., Allan, J. D., Coe, H., Ng, N. L., Aiken, A. C., Docherty, K. S., Ulbrich, I. M., Grieshop, A. P., Robinson, A. L., Duplissy, J., Smith, J. D., Wilson, K. R., Lanz, V. A., Hueglin, C., Sun, Y. L., Tian, J., Laaksonen, A., Raatikainen, T., Rautiainen, J., Vaattovaara, P., Ehn, M., Kulmala, M., Tomlinson, J. M., Collins, D. R., Cubison, M. J., Dunlea, E. J., Huffman, J. A., Onasch, T. B., Alfarra, M. R., Williams, P. I., Bower, K., Kondo, Y., Schneider, J., Drewnick, F., Borrmann, S., Weimer, S., Demerjian, K., Salcedo, D., Cottrell, L., Griffin, R., Takami, A., Miyoshi, T., Hatakeyama, S., Shimono, A., Sun, J. Y., Zhang, Y. M., Dzepina, K., Kimmel, J. R., Sueper, D., Jayne, J. T., Herndon, S. C., Trimborn, A. M., Williams, L. R., Wood, E. C., Middlebrook, A. M., Kolb, C. E., Baltensperger, U., and Worsnop, D. R.: Evolution of organic aerosols in the atmosphere, Science, 326, 1525-1529, 2009.

Kanakidou, M., Seinfeld, J. H., Pandis, S. N., Barnes, I., Dentener, F. J., Facchini, M. C., Van Dingenen, R., Ervens, B., Nenes, A., Nielsen, C. J., Swietlicki, E., Putaud, J. P., Balkanski, Y., Fuzzi, S., Horth, J., Moortgat, G. K., Winterhalter, R., Myhre, C. E. L., Tsigaridis, K., Vignati, E., Stephanou, E. G., and Wilson, J.: Organic aerosol and global climate modelling: a review, Atmos. Chem. Phys., 5, 1053-1123, doi:10.5194/acp-5-1053-2005, 2005.

Kaul, D. S., Gupta, T., Tripathi, S. N., Tare, V., and Collett, J. L.: Secondary Organic Aerosol: A Comparison between Foggy and Nonfoggy Days, Environ. Sci. Technol., 45, 7307-7313, 2011.

Kroll, J. H., Donahue, N. M., Jimenez, J. L., Kessler, S. H., Canagaratna, M. R., Wilson, K. R., Altieri, K. E., Mazzoleni, L. R., Wozniak, A. S., Bluhm, H., Mysak, E. R., Smith, J. D., Kolb, C. E., and Worsnop, D. R.: Carbon oxidation state as a metric for describing the chemistry of atmospheric organic aerosol, Nature Chem., 3, 133-139, 2011.

Lambe, A. T., Onasch, T. B., Massoli, P., Croasdale, D. R., Wright, J. P., Ahern, A. T., Williams, L. R., Worsnop, D. R., Brune, W. H., and Davidovits, P.: Laboratory studies of the chemical composition and cloud condensation nuclei $(\mathrm{CCN})$ activity of secondary organic aerosol (SOA) and oxidized primary organic aerosol (OPOA), Atmos. Chem. Phys., 11, 8913-8928, doi:10.5194/acp11-8913-2011, 2011.

Lanz, V. A., Alfarra, M. R., Baltensperger, U., Buchmann, B., Hueglin, C., and Prévôt, A. S. H.: Source apportionment of submicron organic aerosols at an urban site by factor analytical modelling of aerosol mass spectra, Atmos. Chem. Phys., 7, 15031522, doi:10.5194/acp-7-1503-2007, 2007.

Lathem, T. L., Beyersdorf, A. J., Thornhill, K. L., Winstead, E. L., Cubison, M. J., Hecobian, A., Jimenez, J. L., Weber, R. J., Anderson, B. E., and Nenes, A.: Analysis of CCN activity of Arctic aerosol and Canadian biomass burning during summer 2008, Atmos. Chem. Phys., 13, 2735-2756, doi:10.5194/acp-13-27352013, 2013. 
Lee, A. K. Y., Herckes, P., Leaitch, W. R., Macdonald, A. M., and Abbatt, J. P. D.: Aqueous OH oxidation of ambient organic aerosol and cloud water organics: Formation of highly oxidized products, Geophys. Res. Lett., 38, L11805, doi:10.1029/2006g1028457, 2011.

Lee, B. Y. L., Li, Y. J., and Chan, C. K.: Characteristics of ambient aerosol at a suburban site in Hong Kong during springtime, J. Geophys. Res.-Atmos., 118, doi:10.1002/jgrd.50658, 2013.

Li, Y. J., Chen, Q., Guzman, M. I., Chan, C. K., and Martin, S. T.: Second-generation products contribute substantially to the particle-phase organic material produced by beta-caryophyllene ozonolysis, Atmos. Chem. Phys., 11, 121-132, 2011 a.

Li, Y. J., Yeung, J. W. T., Leung, T. P. I., Lau, A. P. S., and Chan, C. K.: Characterization of Organic Particles from Incense Burning Using an Aerodyne High-Resolution Time-of-Flight Aerosol Mass Spectrometer, Aerosol Sci. Technol., 46, 654-665, $2011 \mathrm{~b}$.

Louie, P. K. K., Watson, J. G., Chow, J. C., Chen, A., Sin, D. W. M., and Lau, A. K. H.: Seasonal characteristics and regional transport of $\mathrm{PM}_{2.5}$ in Hong Kong, Atmos. Environ., 39, 1695-1710, 2005.

Martin, M., Tritscher, T., Juranyi, Z., Heringa, M. F., Sierau, B., Weingartner, E., Chirico, R., Gysel, M., Prevot, A. S. H., Baltensperger, U., and Lohmann, U.: Hygroscopic properties of fresh and aged wood burning particles, J. Aerosol Sci., 56, 1529, 2013.

Massoli, P., Lambe, A. T., Ahern, A. T., Williams, L. R., Ehn, M., Mikkila, J., Canagaratna, M. R., Brune, W. H., Onasch, T. B., Jayne, J. T., Petaja, T., Kulmala, M., Laaksonen, A., Kolb, C. E., Davidovits, P., and Worsnop, D. R.: Relationship between aerosol oxidation level and hygroscopic properties of laboratory generated secondary organic aerosol (SOA) particles, Geophys. Res. Lett., 37, L24801, doi:10.1029/2010g1045258, 2010.

Middlebrook, A. M., Bahreini, R., Jimenez, J. L., and Canagaratna, M. R.: Evaluation of Composition-Dependent Collection Efficiencies for the Aerodyne Aerosol Mass Spectrometer using Field Data, Aerosol Sci. Technol., 46, 258-271, 2012.

Morgan, W. T., Allan, J. D., Bower, K. N., Highwood, E. J., Liu, D., McMeeking, G. R., Northway, M. J., Williams, P. I., Krejci, R., and Coe, H.: Airborne measurements of the spatial distribution of aerosol chemical composition across Europe and evolution of the organic fraction, Atmos. Chem. Phys., 10, 4065-4083, doi:10.5194/acp-10-4065-2010, 2010.

Ng, N. L., Kroll, J. H., Keywood, M. D., Bahreini, R., Varutbangkul, V., Flagan, R. C., Seinfeld, J. H., Lee, A., and Goldstein, A. H.: Contribution of first- versus second-generation products to secondary organic aerosols formed in the oxidation of biogenic hydrocarbons, Environ. Sci. Technol., 40, 2283-2297, 2006.

Ng, N. L., Canagaratna, M. R., Zhang, Q., Jimenez, J. L., Tian, J., Ulbrich, I. M., Kroll, J. H., Docherty, K. S., Chhabra, P. S., Bahreini, R., Murphy, S. M., Seinfeld, J. H., Hildebrandt, L., Donahue, N. M., DeCarlo, P. F., Lanz, V. A., Prévôt, A. S. H., Dinar, E., Rudich, Y., and Worsnop, D. R.: Organic aerosol components observed in Northern Hemispheric datasets from Aerosol Mass Spectrometry, Atmos. Chem. Phys., 10, 46254641, doi:10.5194/acp-10-4625-2010, 2010.

Ng, N. L., Canagaratna, M. R., Jimenez, J. L., Chhabra, P. S., Seinfeld, J. H., and Worsnop, D. R.: Changes in organic aerosol composition with aging inferred from aerosol mass spectra, Atmos. Chem. Phys., 11, 6465-6474, doi:10.5194/acp-11-64652011, 2011.
Pankow, J. F.: An absorption model of the gas aerosol partitioning involved in the formation of secondary organic aerosol, Atmos. Environ., 28, 189-193, 1994.

Pankow, J. F.: Organic particulate material levels in the atmosphere: Conditions favoring sensitivity to varying relative humidity and temperature, P. Natl. Acad. Sci. USA, 107, 6682-6686, 2010.

Shilling, J. E., Chen, Q., King, S. M., Rosenoern, T., Kroll, J. H., Worsnop, D. R., DeCarlo, P. F., Aiken, A. C., Sueper, D., Jimenez, J. L., and Martin, S. T.: Loading-dependent elemental composition of $\alpha$-pinene SOA particles, Atmos. Chem. Phys., 9, 771-782, doi:10.5194/acp-9-771-2009, 2009.

Sorooshian, A., Murphy, S. M., Hersey, S., Bahreini, R., Jonsson, H., Flagan, R. C., and Seinfeld, J. H.: Constraining the contribution of organic acids and AMS $m / z \quad 44$ to the organic aerosol budget: On the importance of meteorology, aerosol hygroscopicity, and region, Geophys. Res. Lett., 37, L21807, doi:10.1029/2010g1044951, 2010.

Sueper, D.: ToF-AMS data analysis software: http://cires.colorado. edu/jimenez-group/ToFAMSResources/ToFSoftware/index. html, (last access: 1 June), 2011.

Tan, Y., Perri, M. J., Seitzinger, S. P., and Turpin, B. J.: Effects of Precursor Concentration and Acidic Sulfate in Aqueous GlyoxalOH Radical Oxidation and Implications for Secondary Organic Aerosol, Environ. Sci. Technol., 43, 8105-8112, 2009.

Ulbrich, I. M., Canagaratna, M. R., Zhang, Q., Worsnop, D. R., and Jimenez, J. L.: Interpretation of organic components from Positive Matrix Factorization of aerosol mass spectrometric data, Atmos. Chem. Phys., 9, 2891-2918, doi:10.5194/acp-9-2891-2009, 2009.

Wang, T., Ding, A. J., Blake, D. R., Zahorowski, W., Poon, C. N., and Li, Y. S.: Chemical characterization of the boundary layer outflow of air pollution to Hong Kong during February-April 2001, J. Geophys. Res.-Atmos., 108, 8787, doi:10.1029/2002jd003272, 2003.

Wong, J. P. S., Lee, A. K. Y., Slowik, J. G., Cziczo, D. J., Leaitch, W. R., Macdonald, A., and Abbatt, J. P. D.: Oxidation of ambient biogenic secondary organic aerosol by hydroxyl radicals: Effects on cloud condensation nuclei activity, Geophys. Res. Lett., 38, L22805, doi:10.1029/2011g1049351, 2011.

Wood, E. C., Canagaratna, M. R., Herndon, S. C., Onasch, T. B., Kolb, C. E., Worsnop, D. R., Kroll, J. H., Knighton, W. B., Seila, R., Zavala, M., Molina, L. T., DeCarlo, P. F., Jimenez, J. L., Weinheimer, A. J., Knapp, D. J., Jobson, B. T., Stutz, J., Kuster, W. C., and Williams, E. J.: Investigation of the correlation between odd oxygen and secondary organic aerosol in Mexico City and Houston, Atmos. Chem. Phys., 10, 8947-8968, doi:10.5194/acp-10-8947-2010, 2010.

Yao, X. H., Fang, M., Chan, C. K., Ho, K. F., and Lee, S. C.: Characterization of dicarboxylic acids in $\mathrm{PM}_{2.5}$ in Hong Kong, Atmos. Environ., 38, 963-970, 2004.

Yu, J. Z., Tung, J. W. T., Wu, A. W. M., Lau, A. K. H., Louie, P. K. K., and Fung, J. C. H.: Abundance and seasonal characteristics of elemental and organic carbon in Hong Kong PM $_{10}$, Atmos. Environ., 38, 1511-1521, 2004.

Yu, J. Z., Huang, X. F., Xu, J. H., and Hu, M.: When aerosol sulfate goes up, so does oxalate: Implication for the formation mechanisms of oxalate, Environ. Sci. Technol., 39, 128-133, 2005. 
Zhang, Q., Jimenez, J. L., Canagaratna, M. R., Ulbrich, I. M., Ng, N. L., Worsnop, D. R., and Sun, Y. L.: Understanding atmospheric organic aerosols via factor analysis of aerosol mass spectrometry: a review, Anal. Bioanal. Chem., 401, 3045-3067, 2011.
Zhang, X. L., Liu, J. M., Parker, E. T., Hayes, P. L., Jimenez, J. L., de Gouw, J. A., Flynn, J. H., Grossberg, N., Lefer, B. L., and Weber, R. J.: On the gas-particle partitioning of soluble organic aerosol in two urban atmospheres with contrasting emissions: 1. Bulk water-soluble organic carbon, J. Geophys. Res.-Atmos., 117, D00v16, doi:10.1029/2012jd017908, 2012. 